\title{
Review
}

\section{Applications of Electrolyzed Water in Agriculture \& Food Industries}

\author{
Muhammad Imran AL-HaQ, ${ }^{1,2}$, Junichi SugrYama ${ }^{1 * *}$ and Seiichiro IsobE ${ }^{1}$ \\ ${ }^{1}$ National Food Research Institute, 2-1-12 Kannondai, Tsukuba, Ibaraki Prefecture 305-8642, Japan \\ ${ }^{2}$ Graduate School of Engineering, The University of Tokyo, 7-3-1 Hongo, Bunkyo-ku, Tokyo 113-8656, Japan
}

Received April 6, 2005; Accepted June 4, 2005

\begin{abstract}
Microbial control of postharvest diseases has been extensively studied and appears to be a viable technology. Food safety must be ensured at each postharvest processing step, including handling, washing of raw materials, cleaning of utensils and pipelines, and packaging. Several commercial products are available for this purpose. The time is ripe for developing new techniques and technologies. The use of electrolyzed water $(\mathrm{EW})$ is the product of a new concept developed in Japan, which is now gaining popularity in other countries. Little is known about the principle behind its sterilizing effect, but it has been shown to have significant bactericidal and virucidal and moderate fungicidal properties. Some studies have been carried out in Japan, China, and the USA on the pre- and postharvest application of EW in the field of food processing. EW may be produced using common salt and an apparatus connected to a power source. As the size of the machine is quite small, the water can be manufactured on-site. Studies have been carried out on the use of $\mathrm{EW}$ as a sanitizer for fruits, utensils, and cutting boards. It can also be used as a fungicide during postharvest processing of fruits and vegetables, and as a sanitizer for washing the carcasses of meat and poultry. It is cost-effective and environment-friendly. The use of EW is an emerging technology with considerable potential.
\end{abstract}

Keywords: Electrolyzed water, acidic, alkaline, basic, oxidized, reduced, food safety, postharvest, environment friendly

\section{Introduction}

It is of utmost importance to maintain the quality of fresh produce at postharvest stage. Microbial control of postharvest diseases in food products has been the subject of extensive study. Research into and development of postharvest technologies are on a fast track. Until recently, the economic and political implications of a safe food supply were underestimated. Worldwide, there are 1.5 billion cases of food-borne illness each year; these illnesses rank among the most common forms of disease in the world. More than 3 million deaths from foodborne illness are recorded per year. In the last 25 years, at least 30 new infectious agents associated with food- and water-borne illnesses have been recognized.

Food safety must be ensured at each postharvest processing step, including handling, washing of raw materials, cleaning of utensils and pipelines, and packaging. Bacterial contamination of food-processing surfaces such as stainless steel, glass, cast iron, polypropylene, and Formica, resulting in food spoilage or transmission of disease, has been extensively reported (Abrishami et al., 1994; Blackman and Frank, 1996; Helke et al., 1995; Zhao et al., 1998). Bacterial contamination can also occur on non-

\footnotetext{
*To whom correspondence should be addresses.

E-mail: imranintokyo@hotmail.com orimran@intellect.pe.u-tokyo.ac.jp

** To whom request for reprints should be send.

E-mail: sugiyama@affrc.go.jp
}

food-contact surfaces such as ceramic tiles, vitreous china, stainless steel, and glassware (found in bathrooms and laundries, microbiological testing laboratories, swimming pools, and medical facilities) if these surfaces are not completely sanitized. These contaminated surfaces can serve as reservoirs of pathogens and transfer disease via hand-to-surface contact (Emori and Gaynes, 1993).

Many commercial disinfecting cleaning agents, such as potassium persulphate, isopropanol, hydrogen peroxide, sodium dichloroisocyanurate, ethanol and phenol derivatives (Aarnisalo et al., 2000), quaternary ammonium compounds, and chlorine (Tuncan, 1993), have been shown to be effective against food-borne pathogens in suspension tests. However, microorganisms attached to surfaces are less susceptible to chemical sanitizers than their freeliving counterparts because sanitizers have a limited ability to penetrate the protective layer of microbial polymers (Frank and Koffi, 1990; Lee and Frank, 1991).

Chlorine rinses are generally used during processing (fruits, vegetables, meat, poultry, etc.) for pathogen reduction. Various other processes have been proposed as alternatives for eliminating or substantially decreasing bacterial populations. These include treatment with trisodium phosphate (Vareltzis et al., 1997; Xiong et al., 1998), cetylpyridinium chloride (Xiong et al., 1998), hydrogen peroxide (Lillard and Thomson, 1983), gamma irradiation (Katta et al., 1991), microwave irradiation (Goksoy et al., 2000), and chilling (Vivien et al., 2000). However, most of 
these processes have been found not to be completely acceptable due to chemical residues, discoloration of chicken carcasses, high cost or limited effectiveness. Therefore, the development of effective sanitizers to reduce or eliminate bacterial populations on food, foodprocessing surfaces, non-food contact surfaces (e.g. floors), etc., is an ongoing subject of interest.

Although several commercial products are available, research is still being conducted into new techniques and technologies. One recent discovery is the possibility of using electrolyzed water as a sanitizer. This is the result of a new concept developed in Japan (A1-Haq and Sugiyama, 2004). There is evidence that electrolyzed water can work better than water and chlorine solutions as a sanitizer of meats, some fresh produce, cutting boards and utensils. It appears that the process allows better access to the uneven surfaces of fruits and vegetables. This is currently a topic of interest in the USA, Canada, Japan, and other developed countries. Electrolyzed water has been introduced to food industries as a novel disinfecting agent.

The first reported use of electrolyzed water was in the production of tofu (Isobe, 2003); basic electrolyzed water (BEW) was used for this purpose. Acidic electrolyzed water (AEW or AcEW), which is a popular disinfectant, has been determined to have a strong bactericidal effect on most known pathogenic bacteria. Table 1 presents a summary of studies of the effect of $\mathrm{AEW}$ on various microorganisms. It acts as a flash disinfectant, although not for Bacillus, Mycobacterium and fungi (Iwasawa and

Table 1. Studies conducted to know the effect of AEW on various microorganisms.

\begin{tabular}{ll}
\hline & \multicolumn{1}{c}{ Organism } \\
\hline & Bacteria \\
1 & Bacillus cereus \\
2. & Campylobacter jenuni \\
3. & Enterobacter aerogenes \\
4. & Erwinia carotovora \\
5. & Escherichia coli $\mathrm{O} 157: \mathrm{H} 7$
\end{tabular}

6. Listeria monocytogenes

7. Psudomonos salanacearum

8. Salmonella Enteritidis

9. Salmonella typhimurium

10. Staphylocococcus aureus

11. Streptococcus

12. Xanthomonas

13. Others

Fungi

14. Aspegillus

15. Botrytis

16. Burkholderia glumae

17. Botryosphaeria

18. Cladosporium

19. Colletotrichum

20. Curvularia

21. Fusarium

22. Helminthosporium

23. Magnaporthe

24. Monilinia

25. Penicillium

26. Phytophthora

27. Tilletia indica

28. Others

29. Viruses

30. Algae, Protozoans, Nematodes
Kim et al. (2000a,b, 2001), Park et al. (2002a)

Kim et al. (2000a,b, 2001), Park et al. (2002a)

Park et al. (2002b)

Robbs et al. (1995)

Albrich et al. (1986), Bari et al. (2003), Kim et al. (2002b), Len et al. (2000, 2002), Koseki et al. (2003, 2004a), Park et al. (2004), Venkitanarayanan et al. (1999a,b), Yang et al. (2003), Yoshida et al. (2001) Aarnisalo et al. (2000), Bari et al. (2003),

Blackman \& Frank (1996), Frank \& Koffi (1990), Kim et al. (2002b), Park et al. (2004), Venkitanarayanan et al. (1999a,b), Yang et al. (2003), Zhao et al. (2001)

Matsuoka \& Kawasaki (1994)

Bari et al. (2003), Koseki et al. (2004), Stan et al. (2003), Venkitanarayanan et al. (1999a)

Suzuki et al. (2002b), Yang et al. (2003)

Park et al. (2002b), Suzuki et al. (2002a)

Hotta et al. (1994)

Lazarovits et al. (2004)

Moriyama et al. (2002), Nakagawa et al. (1998),

Suzuki (1996), Tagaki et al. (1997)

Buck et al. (2002), Hara et al. (2003c), Suzuki et al. (2002b)

Buck et al. (2002)

Oomori et al. (2000b)

Al-Haq et al. (2000, 2001a, 2002a)

Buck et al. (2002)

$\mathrm{Al}-\mathrm{Haq}$ et al. $(2003 \mathrm{a}, \mathrm{b})$

Buck et al. (2002)

Grech \& Rijkenberg (1992)

Buck et al. (2002)

Tamaki et al. (2001)

Al-Haq et al. (2001b, 2002b)

Buck et al. (2002)

Grech \& Rijkenberg (1992)

Bonde et al. (1998, 1999a,b), Bonde \& Nester (2002)

Schoerner \& Yamaki (1997, 1999a,b); Fujiwara et al. (1998a,b)

Iwasawa (1993), Kawasaki et al. (2003), Shimizu

(1994)

Grech \& Rijkenberg (1992) 
Nakamura, 1999a). It has also been reported to suppress fungal rot in fruits (Table 1). Studies have shown that AEW is highly effective in reducing or eliminating foodborne pathogens on kitchen boards and on various food products, such as fish, poultry, fruits, and vegetables, on which it reduced populations of pathogens to undetectable levels. A summary of applications of AEW at preand postharvest stages in the agriculture and food industries is presented in Table 2.

\section{Electrolyzed Water}

\section{1 History}

Water electrolysis technology was first used around 1900 in the soda industry, including in the production of sodium hypochlorite (Japan Soda Industry Association, 1982). In 1980, the technology was introduced into the market as sanitary supervision of stored water in an automatic dispenser (Iseki et al., 2002). With improvement and miniaturization of the equipment, electrolysis technology has been applied in various fields and is now regarded as a promising non-thermal treatment for hygiene control (Yoshida, 2003).

\subsection{Terminology}

Acidic electrolyzed water (AEW) has been classified as functional water; some scientists use the term electrolyzed oxidizing water (EO water). Similarly, alkaline electrolyzed water (A1EW) has been referred to as electrolyzed reducing (ER) water or basic electrolyzed water (BEW). Scientists have given various names to the water collected from the anode, a few of which are listed in Table 3. As some Japanese scientists believe that oxidationreduction potential (ORP) is not the principle behind the sterilizing effect of $\mathrm{AEW}$, they prefer the term $\mathrm{AEW}$ or $\mathrm{EO}$ water. In this article, therefore, the terms $\mathrm{AEW}$ and $\mathrm{BEW}$ have been used.

\subsection{Generation of Electrolyzed water}

Electrolyzed water is generated in a cell containing inert positively charged and negatively charged electrodes separated by a septum (membrane or diaphragm) (Fig. 1). The current passing through the electrolyzed-water generator and voltage between the electrodes are set at $8 \sim 10$ amperes and $9 \sim 10$ volts, respectively. A saturated $\mathrm{NaCl}$ (or $\mathrm{KCl} / \mathrm{MgCl}_{2}$ ) solution and tap water from the laboratory supply line are simultaneously introduced into the

Table 2. Application of AEW at pre- and postharvest stages in agriculture and food industries.

\begin{tabular}{|c|c|}
\hline Application & References \\
\hline \multicolumn{2}{|c|}{ Pre-harvest applications } \\
\hline Seed disinfection & $\begin{array}{l}\text { Bonde et al. (1999), Bonde \& Nester (2002), Stan et } \\
\text { al. (2003), Yoshida et al. (2003) }\end{array}$ \\
\hline $\begin{array}{l}\text { Crop disinfection/pre-harvest } \\
\text { disease control }\end{array}$ & $\begin{array}{l}\text { Matsuo (1995a,b), Matsuo \& Takahashi (1997a,b), } \\
\text { Matsuoka \& Kawasaki (1994), Matsuoka et al. } \\
\text { (1994), Tamaki et al. }(2001)\end{array}$ \\
\hline $\begin{array}{l}\text { Irrigational water for microbial } \\
\text { control }\end{array}$ & Grech \& Rijkenberg (1992), Buck et al. (2003) \\
\hline $\begin{array}{l}\text { Spraying as fungicide to control } \\
\text { plant diseases }\end{array}$ & $\begin{array}{l}\text { Buck et al. (2003), Fujiwara et al. (1998a,b), Kang et } \\
\text { al. (2002), Schoerner \& Yamaki (1997, 1999a,b), } \\
\text { Yamaki \& Schoerner (1995) }\end{array}$ \\
\hline Applications of electrolyzed water & Kubota (1996) \\
\hline \multicolumn{2}{|c|}{ Post-harvest applications } \\
\hline $\begin{array}{l}\text { Decontamination by ice cubes of } \\
\text { EO water }\end{array}$ & Koseki et al. (2002) \\
\hline Disinfection cutting boards, etc. & $\begin{array}{l}\text { Abrishami et al. (1994), Venkitanarayan et al. } \\
(1999 \mathrm{a}, \mathrm{b})\end{array}$ \\
\hline Disinfecting fresh leafy & Izumi (1999), Izumi \& Ebihara (2001), Koseki \& Itoh \\
\hline $\begin{array}{l}\text { Vegetables (cabbage, cilantro, } \\
\text { spinach, lettuce) }\end{array}$ & $\begin{array}{l}\text { (2000a,b,c;e 2001a,b, 2002), Koseki et al. (2001, } \\
\text { 2002, 2003), Park et al. (2001), Koseki et al. (2004a), } \\
\text { Ueno et al. (1999), Wang et al. (2004), Yang et al. } \\
\text { (2003) }\end{array}$ \\
\hline Fish & Ueno et al. (1999) \\
\hline Food sanitation management & Kato (1999), Suzuki $(1996,1999)$ \\
\hline $\begin{array}{l}\text { Inactivation of food related } \\
\text { pathogens (bacteria) }\end{array}$ & $\begin{array}{l}\text { Kim et al. (2000a,b; 2001), Koseki et al. }(2004 \mathrm{~b}) \text {, } \\
\text { Park et al. (2004), Suzuki et al. }(2002 \mathrm{~b}) \text {, } \\
\text { Venkitanarayan et al. }(1999 \mathrm{a}, \mathrm{b})\end{array}$ \\
\hline $\begin{array}{l}\text { Postharvest application to control } \\
\text { fungal decay }\end{array}$ & $\begin{array}{l}\text { Al-Haq et al. (2000, 2001a,b; 2002a,b,c; 2003a,b), } \\
\text { Al-Haq \& Sugiyama (2004), Koseki et al. (2004b), } \\
\text { Schoerner \& Yamaki (1997, 1999a,b), Yamaki } \\
\text { (1998), Yamaki \& Schoerner }(1995,1996,1997)\end{array}$ \\
\hline $\begin{array}{l}\text { Postharvest application to control } \\
\text { bacterial decay }\end{array}$ & $\begin{array}{l}\text { Isobe (2002), Izumi (1999), Koseki \& Itoh (2000a,b; } \\
\text { 2001), Koseki et al. (2001, 2002), Park et al. (2002a) }\end{array}$ \\
\hline Poultry & Park et al. $(2002 \mathrm{a})$ \\
\hline
\end{tabular}


equipment. The display indicators (amperes, volts, pH/ ion meters) are continuously observed until the machine stabilizes. The cell electrolyzes the water, resulting in two types of water, possessing different properties, which may be collected from their respective outlets:

(a) An electrolyzed basic solution (BEW, or ER water or AlEW) from the cathode stream ( $\mathrm{pH}$ 11.4, ORP-795 mV), which has strong reducing potential.

(b) An electrolyzed acid solution (AEW, or EO water or AcEW) from the anode stream $(\mathrm{pH} 2.5, \mathrm{OPR}>1,100 \mathrm{mV}$, chlorine base reactants 10 to $90 \mathrm{ppm}$ ), which has a strong bactericidal effect (Anonymous, 1997).

The $\mathrm{pH}$ and ORP are recorded by a $\mathrm{pH} /$ ion meter. The $\mathrm{pH}$, ORP, and free chlorine concentration of electrolyzed water manufactured from tap water has been found to be nearly identical to that produced from distilled water (Bonde et al., 1999). AEW and BEW are collected in separate containers. Electrolyzed water is usually prepared just before use, but studies have been conducted into the possibilities of preserving the water in darkness (Len et al., 2002) and converting it into ice cubes for later use (Koseki et al., 2002). Some scientists have also used electrolyzed neutral water (Hirano and Ueda, 1997), which has a $\mathrm{pH}$ near 7 , for disinfection of food materials.

Formulae for the anodic and cathodic reactions are summarized in Figs. 2 and 3.

\subsection{Types of Electrolyzed Water-Producing Machines}

Various types of electrolyzed water-producing machines are available in the market. As the country that introduced this technology, Japan is the biggest manufacturer of such machines. Sumida (1998) mentioned four models, viz. type I, type II, type $1 \mathrm{~S}$, and type 3 , which produced $\mathrm{AEW}$ of $\mathrm{pH} 2.3 \sim 3.5,2.5 \sim 3.5,3.0 \sim 4.0$, and $5.0 \sim$ 6.0 , respectively.

Generally speaking, machines can be divided into two types: those containing a diaphragm (septum or membrane) produce AEW with a $\mathrm{pH}$ between 2 and 3, while those without a septum produce neutral water at $\mathrm{pH} 6.8$, because $\mathrm{HCl}$ formed at the anode side neutralizes the

Table 3. Various names used by scientists for the AEW.

\begin{tabular}{|c|c|c|}
\hline Name Given & $\begin{array}{l}\text { Abbreviat } \\
\text { ion used }\end{array}$ & References \\
\hline Acid Oxidizing Water & AOW & Shimada et al. (2000) \\
\hline Acidic Electrolyzed & AEW, & Al-Haq et al. (2000), Bari et al. (2003), Buck et \\
\hline Water & $\begin{array}{l}\text { AcEW, } \\
\text { AcE water }\end{array}$ & $\begin{array}{l}\text { al. (2002, 2003), Bonde \& Nester (2002), } \\
\text { Bonde et al. (1999), Isobe (2002, 2003), } \\
\text { Iwasawa (1993), Iwasawa \& Nakamura } \\
(1999 \mathrm{a} / \mathrm{b}) \text {, Koseki \& Itoh (2001a,b; 2002), } \\
\text { Koseki et al. (2001, 2002, 2003, 2004a,b), } \\
\text { Oomori et al. (2002a,b), Tosa \& Yamasaki } \\
\text { (2000), Wang et al. (2004), Yoshida et al. (2002, } \\
2003)\end{array}$ \\
\hline Aqua Oxidation water & & Iwasawa et al., (1993a.b) \\
\hline Chlor-aqueous Solution & & Nakagawa et al. (1998), Suzuki (1999) \\
\hline Electrolyzed $\mathrm{NaCl}$ & & Hotta et al. (194), Suzuki et al. (2002b) \\
\hline
\end{tabular}

Electrolyzed Oxidizing EO water Al-Haq et al. (2001a,b; 2002a,b,c; 2003a,b), Water

Hayashibara et al. (1994), Hsu (2003), Kim et al. (2000a,b, 2001), Len et al. (2000, 2002), Shimada et al. (2000), Park et al. (2004), Venkitanarayanan et al. (1999a,b), Yamanaka (1995), Yamanaka et al. (1995)

Electronically generated Chlorine Water Electronically Prepared Chlorine Water Electrolyzed Strong Acid Aqueous Solution

EPCW Grech \& Rijkenberg (1992)

Electrolyzed Strong Acid Water Functional water ESAAS Kato (1999) Hayashi et al. (1997), Kumon (1999) ESAW Fujiwara et al. (1998a,b)

Iwasawa \& Nakamura (1999b), Kumon (1997),

Nishimoto et al. (1996),

Yamaki (1998), Yamaki \& Shoerner (1995)

Sumida (1998)

Redox Water

Sterilox water Strong Ionized water Selkon et al. (1999), Shetty et al. (1999)

Shiba \& Shiba (1995)

Superoxide water

Selkon et al. (1999), Tanaka et al. (1996) 


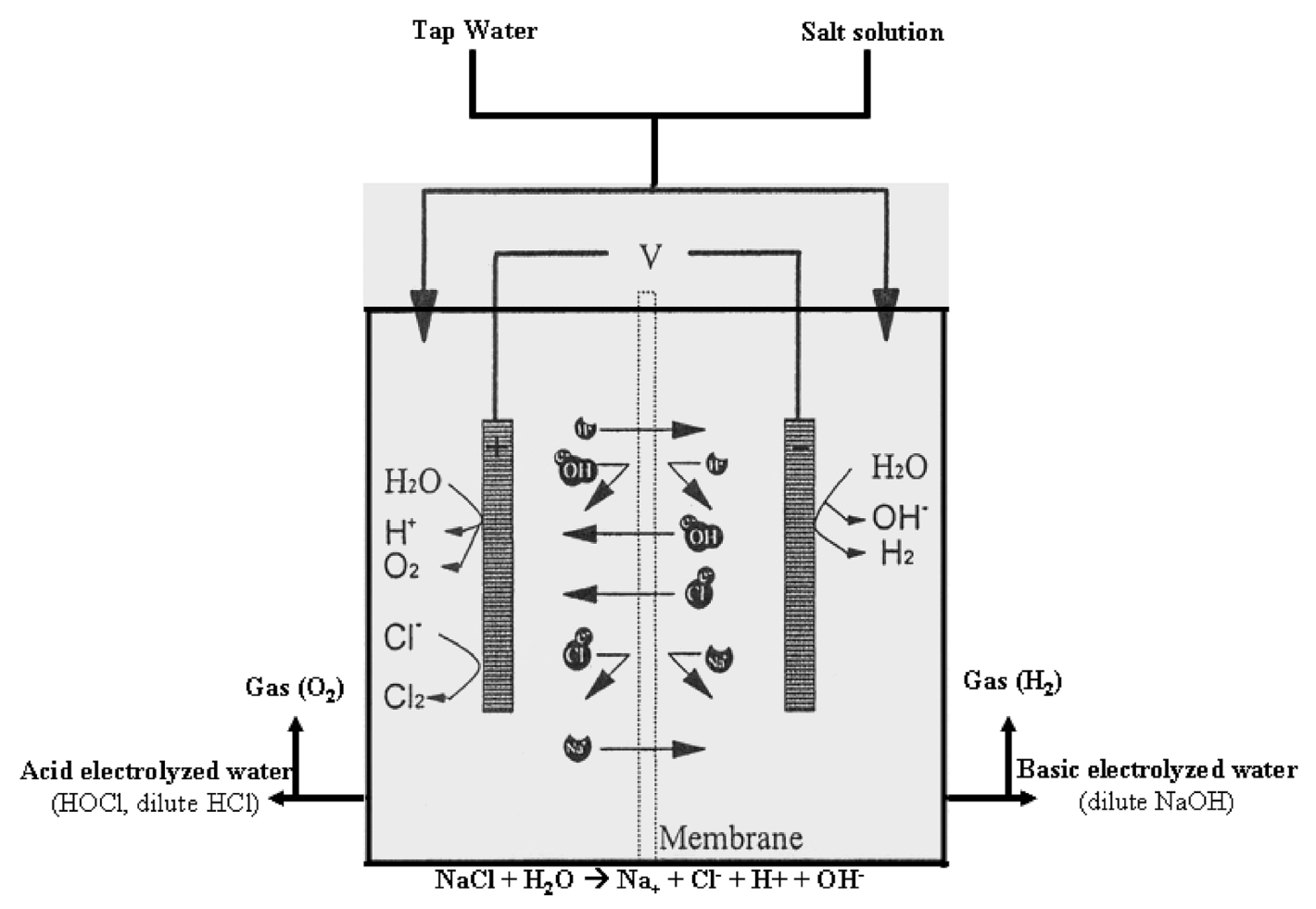

Fig. 1. Schematic of electrolyzed water generator and resulting compounds.

$\mathrm{NaOH}$ at cathode side (Hirano and Ueda, 1997).

Al-Haq and Sugiyama (2004) state that the machine used most commonly in published reports is the ROX-20 TA (Fig. 4, Hoshizaki Electric Inc., Toyoake, Aichi, Japan). This has been used in studies reported by Koseki and Itoh (2000a, b, c, d, 2001); Koseki et al. (2001, 2002); Kim et al. (2000b, 2001); Park et al. (2001, 2002a, b); Venkitanarayanan et al. (1999a, b) and many others. A machine manufactured by Remotex (Remote Co., Toshima-ku, Tokyo) was used by Yamaki (1998) and Yamaki and Schoerner (1995, 1996, 1997). Al-Haq et al. (2000, 2001a, b, 2002a, b, c, 2003a, b) used a machine manufactured by Mitsubishi Electric Engineering Co., Japan (Fig. 5), on which it is possible to set the desired $\mathrm{pH}$ by adjusting the control knobs (Fig. 5), allowing production of electrolyzed neutral water (ENW). ENW, or neutral oxidizing water (NOW), is produced using a non-septum machine and usually has a pH of 5.0 5.5, an ORP of approximately $830 \mathrm{mV}$ and a FAC of approximately $80 \mathrm{ppm}$. In Japan, more than 20 companies manufacture electrolyzed water machines.

\subsection{Uses of AEW in agriculture and food industries}

$\mathrm{AEW}$ is used in the medical, dental, food-processing, agriculture, and dairy industries. It is widely used for disinfection purposes in Japanese hospitals and dental clinics. A brief account of its uses in the agriculture and food industries has been summarized in Tables 2 and 4 . AEW has mostly been used for microbial control, but in some studies both AEW and BEW have been used (Table 5).

\subsection{Advantages of AEW}

Disinfection with AEW is more convenient than con- ventional chlorine disinfection for the following reasons:

1) It can be produced on-site.

2) It is produced by simple electrolysis using pure water with no added chemicals except for a dilute salt solution $\left(\mathrm{NaCl}\right.$ or $\mathrm{KCl}$ or $\left.\mathrm{MgCl}_{2}\right)$; it therefore has less adverse impact on the environment (Kim et al., 2000b; Koseki et al., 2002).

3) Its use reduces the cost and hazards associated with the handling, transportation, and storage of concentrated chlorine solution.

4) It is more environment-friendly. In some machines, if the $\mathrm{pH}$ is set lower than 5.0, chlorine gas (Fig. 6) is produced in addition to other species of FAC (e.g. $\mathrm{HOCl}$ and $\mathrm{OCl}^{-}$ions) (Al-Haq et al., 2001b, 2002a). In such cases the operator must protect himself from chlorine fumes. Otherwise, the machines are safe for the environment as well as for the operator (Bonde et al., 1999).

5) To reduce health concerns about the use of chlorinated water, $\mathrm{AEW}$ can be modified to reduce the available chlorine concentration while maintaining its effectiveness against microbes (Kim et al., 2000 b).

6) It reverts to normal water after use, without releasing large amounts of harmful gases such as chlorine (Bonde et al., 1999).

7) Some researchers claim that AEW kills microorganisms physically, and that microorganisms do not acquire resistance.

8) After the initial cost of the electrolysis apparatus, operational expenses are minimal (Bonde et al., 1999). 
1. Generation of free radicals, active oxygen, and hydrogen peroxide

$$
\begin{gathered}
\mathrm{H}_{2} \mathrm{O}=\mathrm{H}^{+}+{ }^{\bullet} \mathrm{OH}+\mathrm{e}^{-} \\
{ }^{\circ} \mathrm{OH}+{ }^{\bullet} \mathrm{OH}=\mathrm{H}_{2} \mathrm{O}_{2} \\
\mathrm{H}_{2} \mathrm{O}={ }^{\bullet} \mathrm{O}+2 \mathrm{H}^{+}+2 \mathrm{e}^{-} \\
\mathrm{O}_{2^{-}}=2 \mathrm{O}+\mathrm{e}^{-}
\end{gathered}
$$

2. Generation of ozone gas

$$
\begin{gathered}
3 \mathrm{H}_{2} \mathrm{O}=\mathrm{O}_{3}+6 \mathrm{H}^{+}+6 \mathrm{e}^{-} \\
\mathrm{O}+\mathrm{O}_{2}+\mathrm{O}_{3}, \mathrm{O}+\mathrm{O}_{2}=\mathrm{O}_{3} \\
\mathrm{O}_{2}+\mathrm{H}_{2} \mathrm{O}=\mathrm{O}_{3}+2 \mathrm{H}^{+}+2 \mathrm{e}^{-}\left(E^{o}=2.07 \mathrm{~V}\right)
\end{gathered}
$$

3. Generation of oxygen gas

$$
\begin{gathered}
2 \mathrm{H}_{2} \mathrm{O}=\mathrm{O}_{2}+4 \mathrm{H}^{+}+4 \mathrm{e}^{-} \\
4 \mathrm{OH}^{-}=\mathrm{O}_{2}+2 \mathrm{H}_{2} \mathrm{O}+4 \mathrm{e}^{-} \\
\mathrm{H}_{2} \mathrm{O}_{2}=\mathrm{O}_{2}+2 \mathrm{H}^{+}+2 \mathrm{e}^{-} \\
2 \mathrm{Cl}_{2}+2 \mathrm{H}_{2} \mathrm{O}=4 \mathrm{H}^{+}+4 \mathrm{Cl}^{-}+\mathrm{O}_{2}
\end{gathered}
$$

4. Generation of oxygen gas and chlorine gas $2 \mathrm{Cl}^{-}+\mathrm{O}_{3}+2 \mathrm{H}^{+}=\mathrm{O}_{2}+\mathrm{Cl}_{2}+\mathrm{H}_{2}$ $2 \mathrm{Cl}^{-}+2 \mathrm{O}_{3}=3 \mathrm{O}_{2}+\mathrm{Cl}_{2}+2 \mathrm{e}^{-}$

5. Generation of chlorine gas and dissolved chlorine

$$
2 \mathrm{Cl}^{-}=\mathrm{Cl}_{2}(\mathrm{~g})+2 \mathrm{e}^{-}\left(E^{o}=1.359 \mathrm{~V}\right)
$$

$2 \mathrm{HOCl}+2 \mathrm{H}^{+}+2 \mathrm{e}^{-}=\mathrm{Cl}_{2}+2 \mathrm{H}_{2} \mathrm{O}\left(E^{o}=1.63 \mathrm{~V}\right)$

$$
\mathrm{Cl}_{2}(\mathrm{~g})=\mathrm{Cl}_{2}(\mathrm{aq})
$$

6. Generation of hypochlorous acid and hypochloric acid

$$
\begin{gathered}
\mathrm{Cl}_{2(\mathrm{aq})}+\mathrm{H}_{2} \mathrm{O}=\mathrm{HCl}\left(=\mathrm{H}^{+}+\mathrm{Cl}^{-}\right)+\mathrm{HOCl} \\
\mathrm{Cl}^{-}+\mathrm{H}_{2} \mathrm{O}=\mathrm{HOCl}+\mathrm{H}^{+}+2 \mathrm{e}^{-} \\
2 \mathrm{Cl}^{-}+\mathrm{H}_{2} \mathrm{O}=\mathrm{HOCl}+\mathrm{HCl}+2 \mathrm{e}^{-} \\
2 \mathrm{Cl}^{-}+\mathrm{H}_{2} \mathrm{O}_{2}=2 \mathrm{HOCl}+2 \mathrm{e}^{-} \\
\mathrm{ClO}^{-}+\mathrm{H}_{2} \mathrm{O}=\mathrm{HOCl}+\mathrm{OH}^{-}
\end{gathered}
$$

7. Generation of hypochlorite ion, etc.

$$
\begin{gathered}
\mathrm{Cl}_{2(\text { aq) }}+2 \mathrm{OH}^{-}=\mathrm{ClO}^{-}+\mathrm{Cl}^{-}+\mathrm{H}_{2} \mathrm{O} \\
\mathrm{Cl}_{2(\text { aq })}+\mathrm{H}_{2} \mathrm{O}=\mathrm{ClO}^{-}+\mathrm{Cl}^{-}+2 \mathrm{H}^{+} \\
\mathrm{HOCl}=\mathrm{ClO}^{-}+\mathrm{H}^{+} \\
2 \mathrm{HOCl} \mathrm{ClO}^{-}=\mathrm{ClO}_{3}^{-}+2 \mathrm{Cl}^{-}+2 \mathrm{H}^{+}
\end{gathered}
$$

Fig. 2. Reaction formulae at anodic side.

1. Generation of hydrogen gas

$$
\begin{gathered}
2 \mathrm{H}_{2} \mathrm{O}+2 \mathrm{e}^{-}=\mathrm{H}_{2}+2 \mathrm{OH}^{-}\left(E^{o}=-0.828 \mathrm{~V}\right) \\
2 \mathrm{H}_{2} \mathrm{O}=\mathrm{H}_{2}+2^{\circ} \mathrm{OH}
\end{gathered}
$$

2. Generation of hydrogen and sodium hydrate

$$
\begin{gathered}
2 \mathrm{Na}^{+}+2 \mathrm{H}_{2} \mathrm{O}+2 \mathrm{e}^{-}=\mathrm{H}_{2}+2 \mathrm{NaOH} \\
2 \mathrm{Na}+2 \mathrm{H}_{2} \mathrm{O}=\mathrm{H}_{2}+2 \mathrm{NaOH} \\
\mathrm{Na}^{+}+\mathrm{OH}^{-}=\mathrm{NaOH}
\end{gathered}
$$

3. Generation of hydroxide ion and separation of sodium

$$
\begin{gathered}
\mathrm{Na}^{+}+\mathrm{e}^{-}=\mathrm{Na} \\
2^{\circ} \mathrm{OH}+2 \mathrm{e}^{-}=2 \mathrm{OH}^{-} \\
\mathrm{O}_{2}+2 \mathrm{H}_{2} \mathrm{O}+4 \mathrm{e}^{-}=4 \mathrm{OH}^{-}
\end{gathered}
$$

Fig. 3. Reaction formulae at cathodic side.
Thus, the use of electronically generated chlorine is quite cost-effective. Grech and Rijkenberg (1992) calculated the cost of various methods of chlorination and reported that the unit cost (USA) per kilogram of chlorine (100\% free available) produced was $\$ 1.60$ for liquefied chlorine gas, $\$ 2.70$ for sodium hypochlorite solution $(15 \%, \mathrm{w} / \mathrm{v}), \$ 2.87$ for dry calcium hypochlorite $(70 \%, \mathrm{w} / \mathrm{v}), \$ 3.64$ for TCIA tablets, and 34 cent for electronically generated chlorine.

9) As a non-thermal method, the use of AEW does not result in changes in ingredients, texture, scent, flavor, etc., which are brought about by heat-treatment (Yoshida, 2003).

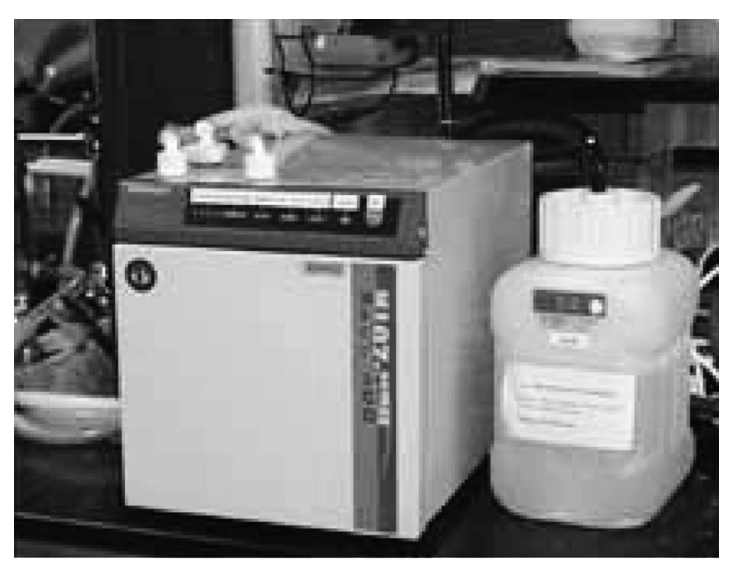

Electrolyzed Oxidizing Water Unit

Fig. 4. The most commonly used electrolyzed waterproducing apparatus.

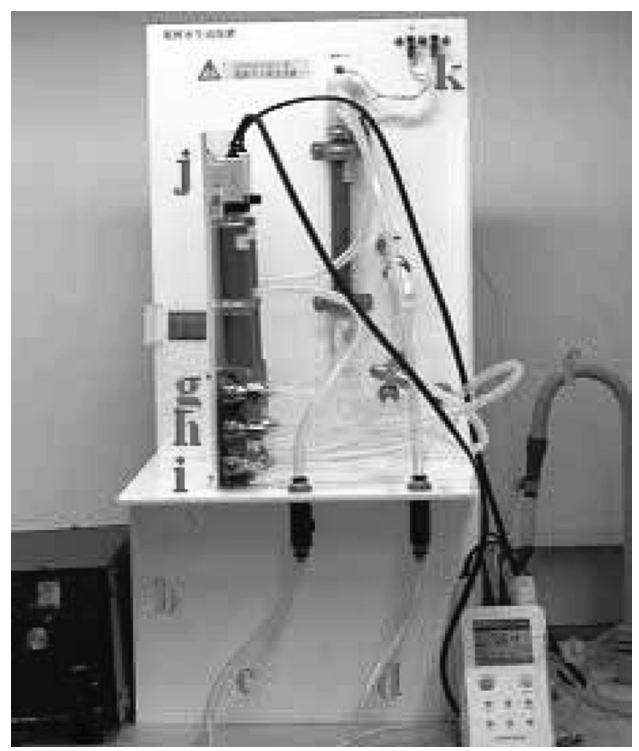

Fig. 5. Equipment used for manufacturing AEW by Al-Haq et al. (2000 ; 2001a, b ; 2002a, b, c ; 2003a, b).

a) electricity generator, b) $\mathrm{NaCl}$ solution tank, c) ACE water outlet, d) ER water outlet, e) $\mathrm{pH} /$ ion meter, f) water supply line, g) Alkali/pH flow control, h) $\mathrm{NaCl}$ / voltage flow control, i) water flow control, j) $\mathrm{pH}$ and ORP electrodes, and k) sterilox cell. 
10) The cytotoxicity of AEW is less than that of a conventional disinfectant.

\subsection{Disadvantages of AEW}

1) It may rust some metals.

2) Its effectiveness is reduced by the presence of protein (Bonde et al., 1999; Iwasawa and Nakamura, 1999) because chlorine reacts with protein (Shimada et al., 1997).

3) Among water-electrolyzing machines, some models, if operated at $\mathrm{pH}<5$, produce pungent chlorine gas that causes discomfort for the operator (Al-Haq et al., 2001b, 2002a).

4) The initial purchase of the equipment may be costly.

5) With time, the bactericidal activity of $\mathrm{AEW}$ is reduced due to chlorine loss (Koseki and Itoh, 2001).

6) $\mathrm{AEW}$ contains free chlorine, which can be phytotoxic to plants and damage plant tissue (Grech and Rijkenberg, 1992; Schubert et al., 1995).

\subsection{Principle of antimicrobial activity of AEW}

The antimicrobial mechanism of AEW is not yet fully understood (Suzuki and Watanabe, 2000). AEW may contain chlorine gas $\left(\mathrm{Cl}_{2}\right), \mathrm{HOCl}$, and $\mathrm{OCl}^{-}$ions, all of which contribute to $\mathrm{FAC}$, i.e. uncombined chlorine radicals (FAC is sometimes referred to as available chlorine concentration, ACC). Some researchers believe that the antimicrobial activity of $\mathrm{AEW}$ is due to the presence of chlorine species, while others believe that the low $\mathrm{pH}$ is responsible. A few studies have suggested that this activity is due to its high ORP. Some scientists say that it is a mixture of all these reasons. The fact remains, however, that AEW possesses strong bactericidal and virucidal and moderate fungicidal properties.

Chlorine is generated at the anode (oxidizing or acidic water), and hydrogen $\left(\mathrm{H}_{2}\right)$ at the cathode (reducing or alkaline water) (Fig. 1). $\quad \mathrm{Cl}_{2}$ reacts with the water to form $\mathrm{HOCl}$ and $\mathrm{HCl}$. At the low $\mathrm{pH}$ of $\mathrm{AEW}, \mathrm{HOCl}$, which is a very weak but effective sanitizer, undergoes virtually no hydrolysis to the much less effective hypochlorite ion $\left(\mathrm{OCl}^{-}\right)$(Kohno, 1996a,b; White, 1992). Hotta (1995) and Kohno (1996b) suggested that the bactericidal action of

Table 4. Studies conducted on various food commodities.

\begin{tabular}{|c|c|}
\hline Commodity & References \\
\hline Alfalfa & Stan et al. (2003) \\
\hline Bell Pepper & Izumi (1999) \\
\hline Cabbage & $\begin{array}{l}\text { Koseki et al. (2000a,b), Koseki \& Itoh (2001b, 2002), Tosa \& } \\
\text { Yamasaki (2000) }\end{array}$ \\
\hline Carrot & Izumi (1999), Izumi \& Ebihara (2001), Izumi \& Suzuki (2000) \\
\hline Cilantro & Wang et al. (2004) \\
\hline Cucumber & $\begin{array}{l}\text { Fujiwara et al. (1998a,b), Izumi \& Ebihara (2001), Koseki et al. } \\
\text { (2004b), Schoerner \& Yamaki (1999a), Yamaki (1998), Yamaki \& } \\
\text { Schoerner (1995) }\end{array}$ \\
\hline Citrus & Grech \& Rijkenberg (1992) \\
\hline Japanese radish & Izumi (1999) \\
\hline Lettuce & $\begin{array}{l}\text { Izumi (1999), Koseki \& Itoh (2000a,b; 2001a,b, 2002), Koseki et } \\
\text { al. (2001, 2002, 2003, 2004), Park et al. (2001, 2002b), Yang et al. } \\
(2003)\end{array}$ \\
\hline Mandarin & Yamaki \& Shoroener (1996) \\
\hline Mango & Al-Haq et al. $(2003 \mathrm{a}, \mathrm{b})$ \\
\hline Melon & Schoerner \& Yamaki (1997) \\
\hline Peach & $\begin{array}{l}\text { Al-Haq et al. (2001b, 2002b), Schoerner \& Yamaki (1999b), } \\
\text { Yamaki (1998), Yamaki \& Schoerner (1997) }\end{array}$ \\
\hline Pear & Al-Haq et al. $(2000,2001 \mathrm{a}, 2002 \mathrm{a})$ \\
\hline Potato & Izumi (1999), Izumi \& Ebihara (2001) \\
\hline Poultry meat & Park et al. $(2002 a)$ \\
\hline Rice & Tamaki et al. (2001), Oomori et al. (2000), Yoshida et al. (2003) \\
\hline Soybeans & Kang et al. (2002) \\
\hline Spinach & Izumi (1999), Izumi \& Ebihara (2001) \\
\hline Strawberry & Koseki et al. (2004b) \\
\hline Tomato & Bari et al. (2003), Matsuoka et al. (1994) \\
\hline Wheat & Bonde et al. $(1998,1999 \mathrm{a}, \mathrm{b})$, Bonde \& Nester (2002) \\
\hline
\end{tabular}

Table 5. Studies in which both AEW and BEW have been employed for microbial control.

\begin{tabular}{lll}
\hline \multicolumn{1}{c}{ Commodity } & \multicolumn{1}{c}{ Organism } & \multicolumn{1}{c}{ Reference } \\
\hline Peach & Monilinia fructicola & Al-Haq et al. (2002b) \\
Lettuce & Escherichia coli $\mathrm{O} 157: \mathrm{H} 7$ & Koseki et al. $(2004)$ \\
& Salmonella Enteritidis & \\
\hline
\end{tabular}




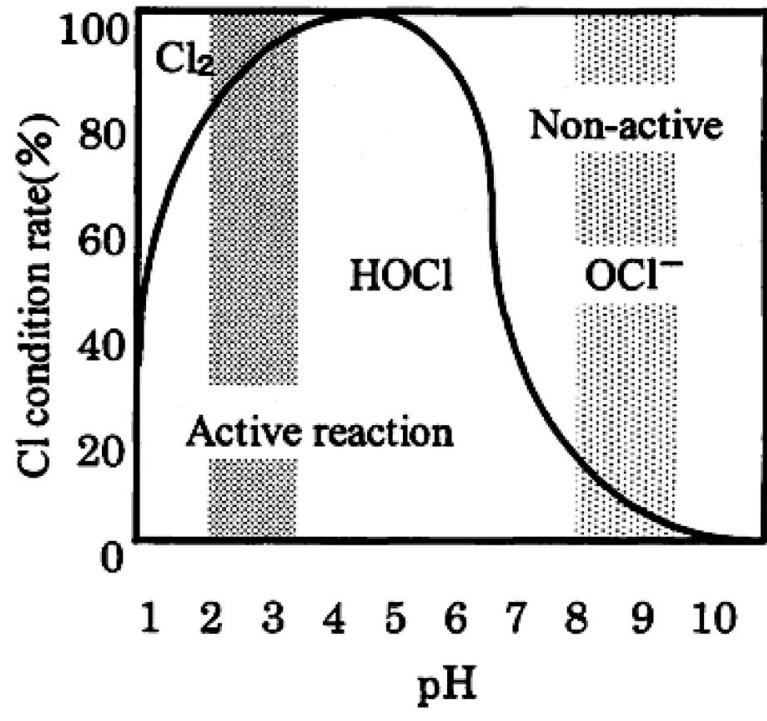

Fig. 6. Chlorine profile change with $\mathrm{pH}$.

$\mathrm{AEW}$ is led by non-equilibrium $\mathrm{HOCl}$, existing at low $\mathrm{pH}$, in the electrolysis process. Studies have also suggested that hypochlorous acid (an undissociated form of chlorine) can penetrate microbial cell membranes and subsequently exert its antimicrobial action through the oxidation of key metabolic systems (Albrich et al., 1986; Barrette et al., 1989; Hurst et al., 1991). Folkes et al. (1995) suggested that reactive $\mathrm{HOCl}$ supplies radical species such as hydroxyl radicals. White (1999) suggested that molecular $\mathrm{Cl}_{2}$ (in equilibrium with $\mathrm{HOCl}$ ), $\mathrm{HOCl}$ and $\mathrm{FAC}$ are the major contributors to the sanitizing effect of AEW. Park et al. (2001) suggested that the concentration of chlorine reactants in AEW is influenced by the amperage of the water generator, but other reports contend that the amount of $\mathrm{HOCl}$ produced during electrolysis is positively correlated with the amount of $\mathrm{NaCl}$ added (Anonymous, 1997; Al-Haq et al., 2001b, 2002a). However, to reduce health concerns about chlorinated water, the manufacture of AEW can be modified to reduce the amount of $\mathrm{HOCl}$ produced while maintaining its effectiveness for microbial inactivation (Kim et al., 2000b; Len et al., 2000).

The $\mathrm{pH}$ value of $\mathrm{AEW}$ also plays a role in restricting microbial growth. Iwasawa et al. (2002) discussed the effect of $\mathrm{pH}$ on the bactericidal properties of $\mathrm{AEW}$; Len $e t$ $a l$. (2000) discussed the influence of amperage and $\mathrm{pH}$ on these properties. In addition, Len et al. (2002) discussed the effect of storage conditions and $\mathrm{pH}$ on chlorine loss in AEW.

Certain scientists have reported that a high ORP is responsible for the antimicrobial activity of AEW (Venkitanarayan et al., 1999; Kim et al., 2000b, 2001; Al-Haq et al., 2002a). The ORP of a solution is an indicator of its ability to oxidize or reduce, with higher positive ORP values corresponding to greater oxidizing strength (Jay, 1996; McPherson, 1993; Robbs et al., 1995). An ORP of +200 to $+800 \mathrm{mV}$ is optimal for growth of aerobic microorganisms, while a range of +200 to $+400 \mathrm{mV}$ is favored for growth of anaerobic microorganisms (Jay,
1996). A possible explanation for the high ORP of AEW is the oxygen released by the rupture of the weak and unstable bond between the hydroxy and chloric radicals (Anonymous, 1997). Kim et al. (2000b) mentioned that the ORP of the treatment solution was the primary factor affecting microbial inactivation. They agreed with reports by McPherson (1993) and Carlson (1991) concerning water disinfection applications, in which the ORP value of the solution was demonstrated to be a better indicator of disinfection properties than the concentration of residual (free) or total chlorine. McPherson (1993) also reported that ORP became a world standard in 1968 when a German Federal Health Office laboratory first proved that the killing rate of E. coli bacteria was dependent on ORP and not on residual chlorine. Carlson (1991) and Robbs et al. (1995) also noted that the killing of bacteria was not based on a defined chlorine reaction and that higher ORP values were required to kill all E. coli in a sample. Hence, a certain chlorine measurement alone cannot guarantee disinfection. However, the ORP provides a single measurement of total oxidation capability, regardless of the $\mathrm{pH}$ and the concentration of chlorine (Kim et al., 2000b). Al-Haq et al. (2002a) suggested that ORP probably plays an influential role, in combination with low $\mathrm{pH}$ and $\mathrm{FAC}$, in the disinfection of $B$. berengeriana on European pear.

A cascade of redox reactions occurs during electrolysis, producing many reactive and toxic compounds, such as ozone, and highly reactive and short-lived radicals such as $\mathrm{O}^{-}, \mathrm{Cl}^{-}$, and $\mathrm{OH}^{-}$in $\mathrm{AEW}$. These compounds contribute to the sanitizing effect of AEW (Shiba and Shiba, 1995).

A significant number of scientists believe that all three factors (chlorine, $\mathrm{pH}$, and high ORP) contribute towards disinfection by AEW (Al-Haq et al., 2002a). However, the presence of chlorine and a high ORP seem to be the main contributors to antimicrobial capacity. Some Japanese scientists believe that ORP is not the reason behind the sterilization effect of AEW and that it should be called $\mathrm{AEW}$ rather than $\mathrm{EO}$ water.

\subsection{Principle of antimicrobial activity of BEW}

BEW (also known as AlEW or ER water) has a pH greater than 11.3 and an ORP of $-800 \mathrm{mV}$ or less. Thus, it has strong reducing potential, which leads to reduction of free radicals in biological systems. It may also be useful in the treatment of organ malfunctions (Kim et al., 2000b). BEW is recognized to have a surface-active effect due to the presence of dilute $\mathrm{NaOH}$, dissolved hydrogen, and active hydrogen (Kikuchi, 2000; Shirahata, 2001; Yamanaka, 1995).

\subsection{Factors affecting activity of AEW}

Storage conditions: One of the limitations of AEW is its loss of bactericidal activity with time, which is caused by chlorine $\left(\mathrm{Cl}_{2}\right)$ loss (Koseki and Itoh, 2000) due to the evaporation of dissolved chlorine gas and ensuing $\mathrm{HOCl}$ decomposition (Fig. 6 and eq. 1). 


$$
\mathrm{Cl}_{2}+\mathrm{H}_{2} \mathrm{O} \leftrightarrow \mathrm{HOCl}+\mathrm{H}^{+}+\mathrm{Cl}^{-}
$$

The free chlorine content of $\mathrm{AEW}$ was found to drop significantly (by 80\%) during 120 min of stirring, while the ORP remained constant, indicating the presence of other strong oxidants (Bonde et al., 1999).

Len et al. (2002) reported that under open conditions, the chlorine in AEW was completely lost after $30 \mathrm{~h}$ when agitated and $100 \mathrm{~h}$ when not agitated. Storage lighting had no significant effect on chlorine loss. First-order kinetics based on chlorine evaporation are not applicable to closed conditions. The primary mechanism of chlorine loss under closed conditions may be the selfdecomposition of chlorine in solution (White, 1999; Gordon, 1992), because chlorine evaporation is limited.

Light: Len et al. (2002) reported that the rate constant for chlorine loss remained almost the same regardless of lighting, indicating that the effect of diffused light on chlorine loss was small under open conditions. Previous1y, El Din et al. (2000) demonstrated that the chlorine decomposition rate for chlorinated water exposed to light was 5 to 8 times higher than the rate for chlorinated water stored in dark; however, the light conditions used in that study were much more intense (direct sunlight at $42 \sim$ $45^{\circ} \mathrm{C}$ ) than the diffused light conditions (373lux) used in the study carried out by Len et al. It was also found that lighting was a more important factor than agitation for chlorine loss under closed conditions. Under given experimental conditions, approximately $60 \%$ of chlorine was lost after $1400 \mathrm{~h}$ when diffused light was applied, whereas about $40 \%$ of chlorine was lost under dark conditions (Len et al., 2002), which suggests that the diffused light induced the decomposition of chlorine during storage.

Agitation: Park et al. (2002b) reported that AEW treatment was less effective without agitation than with agitation, perhaps because of the limited ability of chlorine in $\mathrm{AEW}$ to penetrate attached microbial cell layers. Washing of inoculated surfaces in AEW with agitation at $50 \mathrm{rpm}$ decreased the populations of E. aerogenes and $S$. aureus on different test surfaces to undetectable levels, while the control treatment resulted in a reduction of approximately $3 \log _{10} \mathrm{CFU} / \mathrm{cm}^{2}$ for both bacterial species. The observed reduction after the control treatment could be due to the removal of cells from inoculated surfaces through agitation. No viable cells of either species were observed in AEW after treatment. However, average counts of $4.6 \sim 4.9 \log _{10} \mathrm{CFU} / \mathrm{ml}$ were recovered from the control solutions after treatment, suggesting that significant amounts of attached cells were removed from the inoculated surfaces during agitation (compared with approximately $2.5 \log _{10} \mathrm{CFU} / \mathrm{ml}$ for the treatment without agitation). Without agitation, the TSB medium may react with $\mathrm{AEW}$ to form combined chlorine, reducing the local active chlorine concentration at or near the tested surfaces (Oomori et al., 2000a). Complete inactivation of both species was observed on tested surfaces after AEW treatment with agitation, perhaps because (i) the cells removed from the surfaces during agitation were immedi- ately inactivated in $\mathrm{AEW}$, (ii) agitation facilitates the penetration of $\mathrm{AEW}$ into the remaining cells on the test surface, or (iii) the well-mixed AEW resulting from agitation allows chlorine to react with cells more efficiently (Park et al., 2002b). For a better understanding of the chlorine-loss mechanism under open conditions, Len et al. (2002) calculated the rate constants and reported that the rate of chlorine loss increased by about 5 times when agitation was applied, probably due to the acceleration of interface mass transfer of chlorine gas. Agitation can accelerate mass transfer; however, it would not be expected to affect the decomposition of chlorine species via homogeneous reactions.

$\boldsymbol{p} \boldsymbol{H}$ : The pH of AEW may also affect the rate of chlorine evaporation because the ratio of dissolved chlorine gas to $\mathrm{HOCl}$ in a solution is $\mathrm{pH}$-dependent (White, 1999). The $\mathrm{pH}$ of AEW remained almost unchanged under all storage conditions in both open and closed environments (Len et al., 2002). However, chlorine loss in AEW and chlorinated water was greatly reduced by increasing the pH (Len et al., 2002). They further stated that as the $\mathrm{pH}$ increased from 2.5 to 4.0 , significant decreases in $k$ value (about 10-fold) were observed for both solutions. The decrease in $\mathrm{H}^{+}$concentration with increasing $\mathrm{pH}$ may shift the chemical equilibrium of eq. 1 towards the formation of $\mathrm{HOCl}$, which is not volatile (Shimada et al., 2000). The fraction of volatile dissolved $\mathrm{Cl}_{2}$ gas would therefore decrease, resulting in a reduction of $\mathrm{Cl}_{2}$ evaporation. AEW yielded larger $k$ values than chlorinated water at the same $\mathrm{pH}$, probably due to the different chemical environments of the two solutions (Len et al., 2002). The form of available chlorine varies depending on the environmental pH (Nakagawa et al., 1998). Theoretically, at pH values of 6.0 and 9.0, the predominant chlorine species in a solution is not dissolved $\mathrm{Cl}_{2}$ gas but $\mathrm{HOCl}$ and $\mathrm{OCl}^{-}$(White, 1999). It was therefore found that rates of $\mathrm{Cl}_{2}$ loss due to the evaporation of dissolved $\mathrm{Cl}_{2}$ gas at these $\mathrm{pH}$ values were not significantly different from each other, but were much less than those observed at acidic $\mathrm{pH}$ (Len et al., 2002). There was almost no $\mathrm{Cl}_{2}$ loss at $\mathrm{pH} 9.0$. Len et al. (2002) stated that the observed small rates of $\mathrm{Cl}_{2}$ loss at $\mathrm{pH}$ 6.0 and 9.0 could be due to the self-decomposition of chlorine species, as mentioned for chlorine loss under closed conditions. The change in chlorine profile with $\mathrm{pH}$ is shown in Fig. 6.

ORP: During 120 min stirring of AEW, the ORP remained constant, indicating the presence of other strong oxidants (Bonde et al., 1999). The ORP of AEW was found to decrease during storage, consistent with the loss of oxidative chlorine (Len et al., 2002). The effect of agitation was also clearly shown in the ORP profiles (Len et al., 2002). The effect of lighting on chlorine loss was not clearly observed from the ORP profiles (Len et al., 2002). ORP profiles obtained from closed conditions were similar to each other regardless of agitation and lighting, and only decreased slightly from about 1,100 to $1,085 \mathrm{mV}$ (Len et al., 2002).

Relationship between pH, ORP and FAC: Most of the published work in this area was done using the machine 
shown in Fig. 4, which produces AEW with a $\mathrm{pH}$ of $2.6 \pm$ 0.1. Al-Haq et al. (2002a) used a non-septum machine (Fig. 5) and reported a relationship between $\mathrm{pH}$ and ORP for AEW. The maximum ORP they observed was about $1200 \mathrm{mV}$ at $\mathrm{pH} 2.5 \pm 0.1$; the ORP remained in the range $1170 \pm 20 \mathrm{mV}$ from $\mathrm{pH} 2.6$ to 3.6 .

\section{Effects of AEW on microbes, food commodities and surfaces}

\section{1 Pre-harvest application of AEW : Effect on crops}

Grech and Rijkenberg (1992) injected AEW into a citrus micro-irrigation system to control certain water-borne pathogens, e.g. Phytophthora spp., Fusarium spp., algae, and skin-forming bacteria. All of them were killed. Nematodes were found to resist free-chlorine levels in water up to $50 \mu \mathrm{g} / \mathrm{ml}$. No chlorine-induced phytotoxicity was observed in field-grown plants. In greenhouse studies, treatment levels between 200 and $500 \mu \mathrm{g} / \mathrm{ml}$ significantly reduced propagules of Phytophthora in the soil and, in some cases, eradicated the pathogens.

\subsection{Effect of AEW on bacteria}

Park et al. (2002b) used initial populations of $8.0 \log _{10}$ $\mathrm{CFU} / \mathrm{ml}$ E. aerogenes and $8.04 \log _{10} \mathrm{CFU} / \mathrm{ml}$ of $S$. aureus. Inactivation (reduction of $>9 \log _{10} \mathrm{CFU} / \mathrm{ml}$ ) of $E$. aerogenes and $S$. Aureus occurred within 30 s of exposure to AEW containing approximately 25 or $50 \mathrm{mg} / 1$ of residual chlorine. S. aureus was more resistant than E. aerogenes to diluted AEW containing approximately $10 \mathrm{mg} / 1$ of residual chlorine. After $30 \mathrm{~s}$ of exposure to AEW containing approximately $10 \mathrm{mg} / 1$ of residual chlorine, the population of $E$. aerogenes decreased to an undetectable level; the surviving population of $S$. aureus was $3.9 \log _{10} \mathrm{CFU} /$ ml. Kim et al. (2000b) reported that a 60-s treatment with AEW containing $10 \mathrm{mg} / 1$ of residual chlorine was very effective in reducing the populations of E. coli O157: H7, $L$. monocytogenes, and $B$. cereus vegetative cells to undetectable levels. Zhao et al. (2001) found that most $E$. coli O157: H7 strains were very sensitive to chlorine and that a reduction of $>7 \log _{10} \mathrm{CFU} / \mathrm{ml}$ could be achieved with $0.25 \mathrm{mg} / 1$ of free chlorine.

\subsection{Effect of AEW on test surfaces}

Park et al. (2002b) used initial populations of $6.1 \log _{10}$ $\mathrm{CFU} / \mathrm{cm}^{2}$ of $E$. aerogenes and $S$. aureus regardless of surface type (glass, stainless steel, glazed ceramic tile, unglazed ceramic tile, vitreous china). After immersion of the test surface in $\mathrm{AEW}$ for 5 min without agitation, the populations of $E$. aerogenes and $S$. aureus were reduced by 2.2 to $2.5 \log _{10} \mathrm{CFU} / \mathrm{cm}^{2}$ and by 1.7 to $1.9 \log _{10} \mathrm{CFU} / \mathrm{cm}^{2}$, respectively. Washing of inoculated surfaces with the control solution had only a minimal effect (a reduction of 0.1 and $0.3 \log _{10} \mathrm{CFU} / \mathrm{cm}^{2}$ ). No viable cells of $E$. aerogenes and $S$. aureus were detected in wash solutions immediately after treatment. However, $>2 \log _{10} \mathrm{CFU}$ of viable cells $/ \mathrm{ml}$ were recovered from the control wash solutions after treatment.

\subsection{Effect of AEW on fungi}

Effective postharvest and greenhouse disease management and the use of preventive fungicides are of considerable importance. Increasing concern about pesticides in the environment, potential worker safety issues, and fungicide resistance (LaMondia and Douglas, 1997; Yourman and Jeffers, 1999) indicate the need for alternative disease control measures. AEW is a potential alternative to fungicide in the control of foliar or postharvest diseases. Bonde et al. (1999) carried out a study to determine whether AEW could be used to stimulate germination of Tilletia indica spores, and observed that treatment of wheat seed for 20 min with AEW eliminated contamination by fungi such as Aspergillus, Cladosporium, and Penicillium spp.

AEW has wide fungicidal activity, which may facilitate its use as a contact fungicide on aerial plant surfaces and for general sanitation in greenhouses. It is currently used by some growers, in the form of a spray or as irrigational water, for arresting fungal growth on horticultural crops (Grech and Rijkenberg, 1992; Schoerner and Yamaki, 1997, 1999; Yamaki and Schoerner, 1995). Yamaki (1998) used it for controlling powdery mildew in cucumber and found that it apparently reduced powdery mildew for about two weeks from 18 days after planting. He also found that fungal decay was delayed for about two days in peaches treated with $\mathrm{AEW}$ and for one day in those treated with BEW, while control peaches started to decay the day after harvest. He reported that disease incidence was $70 \%$ in the control, $22 \%$ among $\mathrm{BEW}$ treated peaches and 20\% among AEW-treated peaches.

According to Bonde et al. (1992), AEW destroyed fungi such as Aspergillus, Cladosporium, and Penicillium at short to moderate time durations. This suggests that treatment with AEW may be a suitable replacement for $\mathrm{NaOCl}$ treatment in Karnal bunt disease.

Buck et al. (2002) treated 22 fungal species with AEW in vitro and reported that germination of all 22 fungal species was significantly reduced or prevented. All relatively thin-walled species (e.g. Botrytis, Monilinia) were killed by incubation times of $30 \mathrm{~s}$ or less. Thicker-walled, pigmented fungi (e.g. Curvularia, Helminthosporium) required $2 \mathrm{~min}$ or longer for germination to be reduced significantly. Dilution of AEW with tap water at ratios of 1:4 and 1:9 (AEW: tap water) decreased efficacy against Botrytis cinerea. The presence of Triton X-100 (all concentrations) and Tween 20 (1 and 10\%) eliminated the activity of AEW against $B$. cinerea. AEW did not damage geranium leaf issue and inhibited lesion development by $B$. cinerea when applied up to $24 \mathrm{~h}$ post-inoculation.

Al-Haq et al. (2001b) used AEW for the control of brown rot in peaches. The fruits were inoculated with a spore suspension of $5 \times 10^{5}$ conidia/ml of Monilinia fructicola $[(\mathrm{G}$. Wint.) Honey] applied as a drop on wounded and nonwounded fruits, or as a uniform spray-mist on nonwounded fruits. Fruit were immersed in tap water at $26^{\circ} \mathrm{C}$ for 5 or $10 \mathrm{~min}$ (control), or treated with $\mathrm{AEW}$ of various $\mathrm{ORP}, \mathrm{pH}$, and $\mathrm{FAC}$ values. Following treatment, the fruits were held at $20^{\circ} \mathrm{C}$ and $95 \%$ relative humidity for $\geq 10 \mathrm{~d}$ to simulate retail conditions. Disease incidence 
Table 6. Electrolyzed water in food-product manufacturing.

\begin{tabular}{ll}
\hline Food Product & Reference \\
\hline Bread & Kato et al. (2001), Onishi et al. (1999) \\
Rice & Kobayashi et al. $(1996)$ \\
& Onishi et al. $(2000)$ \\
Tofu & Hara et al. $(2003 \mathrm{~b})$ \\
Wheat Noodles (Udon) & Hara et al. $(2003 \mathrm{a})$ \\
\hline
\end{tabular}

was determined as the percentage of the fruits showing symptoms of the disease, while severity was expressed as lesion diameter. AEW did not control brown rot in wound-inoculated fruits, but reduced disease incidence and severity in non-wounded inoculated peaches. Symptoms of brown rot were further delayed in fruit inoculated by a uniform spray-mist compared with nonwounded drop-inoculated peaches. Fruit treated with AEW and held for $8 \mathrm{~d}$ at $2{ }^{\circ} \mathrm{C}$ and $50 \% \mathrm{RH}$ did not develop brown rot until they were transferred to a $20^{\circ} \mathrm{C}, 95 \% \mathrm{RH}$ environment. The lowest disease incidence and severity occurred in fruit immersed in $\mathrm{AEW}$ for up to $5 \mathrm{~min}$. AEW with pH 4.0, ORP $1,100 \mathrm{mV}$ and FAC $290 \mathrm{mg} / 1$ delayed the onset of brown rot to $7 \mathrm{~d}$, which is roughly the time spent on the market between packing house and consumer. No chlorine-induced phytotoxicity was observed in the treated fruit. This study revealed that AEW is an effective surface sanitizer, but delays rather than preventing disease development.

Al-Haq et al. (2002b) investigated the effectiveness of immersion in $\mathrm{AEW}$ on the control of Bot. rot in European pear (Pyrus communis L.), cv. La France. Four independent experiments were carried out. A wound was found necessary for infection. Wounded fruit were inoculated with $20 \mu \mathrm{L}$ spore suspension of $5 \times 10^{5}$ conidia/ml of Botryosphaeria berengeriana, incubated for four hours, immersed in $\mathrm{AEW}$, and held at $20^{\circ} \mathrm{C}, \geq 90 \% \mathrm{RH}$ (simulated retail conditions) for ripening and disease development. No chlorine-induced phytotoxicity was observed in the treated fruit. AEW was found to suppress disease incidence and severity. The minimum incidence and severity were recorded for a 10-min immersion period. This study also revealed that $\mathrm{AEW}$ is an effective surface sanitizer.

Al-Haq et al. (2003a) studied the effects of AEW on anthracnose of mango [Mangifera indica (L.)] caused by the fungus Colletotrichum gloeosporioides. Fruit were inoculated by applying a spore suspension of $5 \times 10^{5}$ con$\mathrm{idia} / \mathrm{ml}$ of Colletotrichum gloeosporioides and immersed in AEW for varying periods. AEW proved ineffective in controlling anthracnose in wound-inoculated fruits but reduced disease incidence. Symptoms of anthracnose appeared later in fruit treated with AEW than in the control. The minimum disease incidence and severity were recorded for the $\mathrm{AEW}$ immersion periods of up to 30 min. This study revealed that EO water has an effect on C. gloeosporioides, as it suppressed the disease but did not control it.

\section{5 Effect of AEW on cut vegetables}

Izumi (1999) showed that AEW containing 15 to $50 \mathrm{ppm}$ of available chlorine was effective in reducing microbial flora in several fresh-cut vegetables. Koseki et al. (2002) investigated the use of frozen $\mathrm{AEW}$ (in ice cubes, 2 to $3^{\circ} \mathrm{C}$ ) to preserve fresh lettuce during storage in styrene-foam containers for $24 \mathrm{~h}$. They monitored changes in chlorine concentration during storage with tap water ice, AEW ice, and a mixture of $\mathrm{AEW}$ and $\mathrm{BEW}$ ice cubes. The $\mathrm{Cl}_{2}$ concentration increased by $3.9 \mathrm{ppm} / \mathrm{h}$ in the container packed with frozen AEW and $0.5 \mathrm{ppm} / \mathrm{h}$ for a mixture of $\mathrm{AEW}$ and $\mathrm{BEW}$ ice cubes; no increase in $\mathrm{Cl}_{2}$ concentration was observed in the container packed with tap-water ice cubes.

\subsection{Effect of AEW on meat and poultry}

Park et al. (2002a) reported that complete inactivation of Campylobacter jejuni occurred in pure culture within $10 \mathrm{~s}$ after exposure to $\mathrm{AEW}$ or chlorinated water, both of which contained $50 \mathrm{mg} / 1$ of residual chlorine. Strong bactericidal activity was also observed in diluted AEW (containing $25 \mathrm{mg} / 1$ of residual chlorine) and the mean population of $C$. jejuni was reduced to less than $10 \mathrm{CFU} /$ $\mathrm{ml}$ (detected only by enrichment for $48 \mathrm{~h}$ ) after a 10 -s treatment. Diluted chlorinated water $(25 \mathrm{mg} / 1$ residual chlorine) was less effective than diluted AEW for inactivation of $C$. jejuni. AEW was further evaluated for its effectiveness in reducing $C$. jejuni on chicken during washing. AEW and chlorinated water proved equally effective: both achieved reduction of $C$. jejuni by about 3 $\log _{10} \mathrm{CFU} / \mathrm{g}$ on chicken, while treatment with deionized water as a control resulted in a reduction of only $1 \log _{10}$ $\mathrm{CFU} / \mathrm{g}$. No viable cells of $C$. jejuni were recovered in AEW and chlorinated water after washing treatment, but high populations of $C$. jejuni $\left(4 \log _{10} \mathrm{CFU} / \mathrm{ml}\right)$ were recovered in the wash solution after the control treatment. It was further reported that AEW was not only effective in reducing the population of $C$. jejuni on chicken, but also could prevent cross-contamination of processing environments.

\section{Applications of EW in Food Processing}

Table 6 displays a summary of the few studies conducted on the use of $\mathrm{AEW}$ and/or BEW in the manufacture of food products. The use of BEW was found to increase the protein content of tofu (Hara et al., 2003b). It was found that the texture of tofu prepared with BEW and AEW was softer than that of tofu prepared with tap water. No significant difference in free sugar content was observed in tofu prepared with EW compared to that 
prepared with non-EW, but sensory panellists found that tofu prepared with BEW was sweeter than tofu prepared with tap water. Similarly, total carbonyl content, which is related to the substantial taste of tofu, was higher in tofu prepared with $\mathrm{AEW}$ and BEW than in tofu prepared with tap water. It was concluded that the eating quality of tofu may be modified by using EW, especially BEW.

According to Hara et al. (2003a), instrumental measurements and sensory tests of cooked Japanese noodles (Udon) showed that noodles made by kneading wheat flour with AEW were harder and springier than those made by kneading wheat flour with tap water. AEW imparts a favourable texture to the cooked noodles by promoting the dissolution of the gliadin and glutenin subunits that participate in the formation of the gluten matrix. In contrast, the use of $\mathrm{BEW}$ resulted in less springiness suggesting that it changed the gelatinization conditions of starch, which is a negative point. Gelatinization conditions were also changed when wheat starch was heated in EW. A decrease in the maximum and minimum viscosities when the noodles were heated in anode water suggested that the glycosidic linkages of starch molecules were partially hydrolyzed during heating at low $\mathrm{pH}$. When wheat starch was heated in BEW, however, an increase in maximum viscosity and breakdown was observed, suggesting that heating at a high $\mathrm{pH}$ loosens hydrogen bonds, promoting the swelling and breaking of starch molecules. It is likely that when the noodles were cooked in EW, the decay of starch molecules caused the diffusion of large amounts of water into the noodles, resulting in a smaller difference between external and internal hardness. Thus, noodles cooked in EW were less springy than those cooked in tap water. In particular, the use of AEW decreased the springiness of the cooked noodles considerably, and stickiness was significantly increased compared with noodles cooked in tap water. We concluded that AEW was more effective than BEW in modifying the gelatinization conditions of wheat starch. In Japanese food, the springiness of cooked noodles is very important. The use of EW for cooking Japanese wheat noodles (Udon) may not be advisable, because the springiness of the cooked noodles deteriorates as a result.

According to Kobayashi et al. (1996) and Onishi et al. (2000), when weak BEW was used to cook aged rice grains, the cooked rice was found to be softer and stickier, which improved the texture. The quality of cooked rice immediately after cooking was improved by using BEW (Onishi et al., 2000); it was observed that the texture was less hard and the stickiness considerably greater than cooked rice prepared with tap water, but the cooked rice prepared with BEW was found to spoil more quickly. It was further found that by adding a carbohydrate such as trehalose or a surfactant such as polyoxyethylene polyoxypropylene glycerinether monoglyceride to the soaking water, retrogradation of rice cooked with weak BEW could be retarded.

Hoshizaki Electric Inc., Japan, has obtained a US patent on a preparation method for flour dough, e.g. for bread.
EW was used for kneading to enhance the quality of processed foods without using any food additives (Kato et al., 2001). The crumb of bread made with weak AEW had higher elasticity than that of bread made with tap water, and the crumb of bread made with weak BEW was softer than that of bread made with tap water (Onishi et al., 1999).

Sekihan, a Japanese food, consists of rice cooked with azuki beans. Azuki beans give a reddish color to the rice, which is why this dish is often prepared for celebrations in Japan. In fact, for Japanese people the phrase "Let's have sekihan," means that they intend to celebrate something. Kobayashi et al. (2004) studied the effectiveness of $\mathrm{AEW}$ and BEW in changing the color tone and astringency of sekihan. They found that the use of AEW resulted in a considerable reduction in astringency, but the color tone of the boiled azuki bean extract became faint. The use of BEW resulted in deeper color, and the color of the sekihan also became darker.

\section{Conclusions}

AEW treatment may be used as an effective method for reducing microbial contamination not only on food processing surfaces but also on non-food-contact surfaces such as ceramic tiles, floors, stainless steel, laboratory glassware, or medical or dental facilities. The complete inactivation of $S$. aureus and E. aerogenes in AEW after treatment indicated that AEW can also prevent crosscontamination from treatment solutions. AEW shows wide-ranging fungicidal activity, which may facilitate its use as a contact fungicide on aerial plant surfaces and for general sanitation in greenhouses.

As AEW is produced on-site and on demand for direct use, it can also reduce health hazards for workers by eliminating the need to handle concentrated chemicals. It may be useful as a food safety agent. Both AEW and $\mathrm{BEW}$ are useful in food manufacturing, depending on the food being produced. The use of EW is an emerging technology and the door is open to further research and development.

\section{References}

Aarnisalo, K., Salo, S., Miettinen, H., Suihko, M-L., Wirtanen, G., Autio, T., Lunden, J., Korkeala, H. and Sjoberg, A-M. (2000). Bactericidal efficiencies of commercial disinfectants against Listeria monocytogenes on surfaces. J. Food Safety 20, 237-250.

Abe, T. (1999). The cleaning and disinfecting of hemodialysis equipment using electrolyzed strong acid aqueous solution. Proc. 6th Functional Water Symp., Tokyo, Nov 25-26, pp. 42-43. (in Japanese with Abstract in English).

Abrishami, S.H., Tall, B.D., Bruusema, T.J., Epstein, P.S. and Shah, D.B. (1994). Bacterial adherence and viability on cutting board surfaces. J. Food Safety 14, 153-171.

Al-Haq, M.I. and Sugiyama, J. (2004). Application of electrolyzed water in food processing. Presented at 2004 ASAE/CSAE annual meeting, Ottawa, Canada, August 1-4, 2004, ASAE paper No. 04-6178.

Al-Haq, M.I., Seo, Y., Oshita, S. and Kawagoe, Y. (2000). Acidic electrolyzed water suppresses fungal growth on pear. Proc. 59 th Annual Meeting Japanese Soc. Agric. Machinery (JSAM), Niigata, Japan, April 1-3, pp. 479-480. 
Al-Haq, M.I., Seo, Y., Oshita, S. and Kawagoe, Y. (2001a). Effect of postharvest dipping of pear in electrolyzed oxidizing water. Proc. 6th Intl. Symp. Fruit, Nut, and Vegetable Production Engineering, Potsdam, Germany, Sep. 11-19, pp. 333-337.

Al-Haq, M.I., Seo, Y., Oshita, S. and Kawagoe, Y. (2001b). Fungicidal effectiveness of electrolyzed oxidizing water on postharvest brown rot of peach. HortScience 39, 1310-1314.

Al-Haq, M.I., Seo, Y., Oshita, S. and Kawagoe, Y. (2002a). Disinfection effects of electrolyzed oxidizing water on suppressing fruit rot of pear caused by Botryosphaeria berengeriana. Food Res Intl. 35, 657-664.

Al-Haq, M.I., Seo, Y., Oshita, S., Kawagoe, Y. and Sugiyama, J. (2002b). Electrolyzed oxidized water immersion as a packinghouse operation. The J. Functional Water 1 (1), 38.

Al-Haq, M.I., Seo, Y., Oshita, S., Kawagoe, Y., Sugiyama, J. and Nasar-Abbas, S.M. (2002c). Electrolyzed oxidized water-a new technology for postharvest treatment of fruits and vegetables. Proc. 9th JIRCAS Intl. Symp. 'Value-addition to agricultural products - towards increase of farmers' income and vitalization of rural economy', Tsukuba, Japan, Oct 16-17, p. 33.

Al-Haq, M.I., Bari, M.L., Todoroki, S. and Sugiyama, J. (2003a). Fungicidal effectiveness of electrolyzed oxidized water on anthracnose of mango. Proc. United States-Japan Cooperative Program in Natural Resources (UJNR) Food and Agriculture Panel 32nd Annual Meeting, Tsukuba, Japan, Nov 9-15, pp. 454-459.

Al-Haq, M.I., Sugiyama, J., Isobe, S., Kawagoe, Y. and Oshita, S. (2003b). Inactivation of Colletotrichum gloeosporioides spores by electrolyzed oxidizing water. Abst. 2nd Japanese Soc Functional Water Symp., Gifu, Japan, Nov 27-28, p. 25.

Albrich, J.M., Gilbaugh, J.H. III, Callahan, K.B. and Hurst, J.K. (1986). Effects of the putritive neutrophil-generated toxin, hypochlorous acid, on membrane permeability and transport systems of Escharichia coli. J Clin. Invest. 78, 177-184.

Anonymous (1997). "Principle of formation of electrolytic water". Hoshizaki Electric Co. Ltd., Sakae, Toyoake, Aichi, Japan.

Bari, M.L., Sabina, Y., Isobe, S., Uemura, T. and Isshiki, K. (2003). Effectiveness of electrolyzed acidic water in killing Escharichia coli O157: H7, Salmonella Enteritidis, and Listeria monocytogenes on the surface of tomatoes. J. Food Prot. 66, 542-548.

Barrette, W.C. Jr., Hannum, D.M., Wheeler, W.D. and Hurst, J.K. (1989). General mechanism for the bacterial toxicity of hypochlorous acid: abolition of ATP production. Biochemistry 28, 9172-9178.

Blackman, I. and Frank, J.F. (1996). Growth of Listeria monocytogenes as a biofilm on various food-processing surfaces. J. Food Prot. 59, 827-831.

Bonde, M.R. and Nester, S.E. (2002). Acidic electrolyzed water (AEW) for surface sterilization of teliospores. Phytopathology 92 (6), S142.

Bonde, M.R., Nester, S.E., Khayat, A., Frederick, R.D., Peterson, G. L. and Schaad, N.W. (1998). Comparison of sodium hy pochlorite and acidic electrolyzed water to stimulate teliospore germination on Tilletia indica. Phytopathology 88 (9 Suppl.), S9.

Bonde, M.R., Nester, S.E., Khayat, A., Smilanick, J.L., Frederick, R. D. and Schaad, N.W. (1999a). Comparison of effects of acidic electrolyzed water and $\mathrm{NaOCl}$ on Tilletia indica teliospore germination. Plant Dis. 83, 627-632.

Bonde, M.R., Nester, S.E., Smilanick, J.L., Frederick, R.D., Schaad, N.W. and Luster, D.G. (1999b). Use of acidic electrolyzed water to obtain axenic cultures of Tilletia indica wheat or soil samples. Phytopathology 89 (6 Suppl.), S8.

Buck, J.W., van Iersel, M,W., Oetting, R.D. and Hung, Y-C. (2002). In vitro fungicidal activity of acidic electrolyed oxidizing water. Plant Dis. 86, 278-281.

Buck, J.W., van Iersel, M.W., Oetting, R.D. and Hung, Y-C. (2003). Evaluation of acidic electrolyzed water for phytotoxic symp- toms on foliage and flowers of bedding plants. Crop Prot. 22, 7377.

Carlson S. (1991). Fundamentals of water disinfection. Journal of water SRT-aqua, 40, 346-356.

Emori, T.G. and Gaynes, R.P. (1993). An overview of nosocomial infections, including the role of the microbiology laboratory. Clin. Microbiol. Rev. 6, 428-482.

El Din, A.M.S., Arain, R.A. and Hammoud, A.A. (2000). On the chlorination of seawater. Desalination 129, 53-62.

Folkes, L.K., Candeias, L.P. and Wardman, P. (1995). Kinetics and mechanism of hydrochlorous acid reactions. Archives Biochem. Biophy. 323 (1), 120-126.

Frank, J.F. and Koffi, R.A. (1990). Surface-adherent growth of Listeria monocytogenes is associated with increased resistance to surfactant sanitizers and heat. J. Food Prot. 53, 550-554.

Fujiwara, K., Iimoto, M. and Fujiwara, M. (1998a). Fundamental studies on crop disease control by spraying electrolyzed strong acid water (1) Effects of hydrogen-ion concentration exponent and free effective chlorine concentration on the control of powdery mildew on cucumber leaves. Environ Control in Biol. 36, 137-143 (in Japanese).

Fujiwara, K., Doi, R., Iimoto, M. and Shi, Q-C. (1998b). Fundamental studies on crop disease control by spraying electrolyzed strong acid water (2) Control of downy mildew in cucumber and occurrence of a leaf burn-like physiological order. Environ. Control in Biol. 36, 245-249 (in Japanese).

Goksoy, E.O., James, C. and Corry, J.E.L. (2000). The effect of short-time microwave exposures on inoculated pathogens on chicken and the shelf-life of uninoculated chicken meat. J Food Eng. 45, 153-160.

Gordon, G., Cooper, W.J., Rice, R.G. and Pacey, G.E. (1992). Chlorine, chloramines, and the oxy-chlorine species. In "Disinfectant Residual Measurement Methods\#, $2^{\text {nd }}$ edn.: AWWA research Foundation and American Water Works Association, Denver, CO; Chapter 2, pp. 11-62.

Grech, N.M. and Rijkenberg, F.H.J. (1992). Injection of electronically generated chlorine into citrus mirco-irrigation systems for the control of certain waterborne root pathogens. Plant Dis. 76, 457-461.

Hayashi, H., Kumon, K., Yahagi, N., Haruna, M., Watanabe, Y., Matsui, J. and Hattori, R. (1997). Successful treatment of mediastinitis after cardiovascular surgery using electrolyzed strong acid aqueous solution. Artificial Organs 21, 39-42.

Hara, Y., Watanuki, A. and Arai, E. (2003a) Effects of weakly electrolyzed water on properties of Japanese wheat noodles (Udon). Food Sci. Technol. Res. 9 (4), 320-326.

Hara, Y., Matsuda, H. and Arai, E. (2003b) Effects of weakly electrolyzed water on properties of tofu (soybean curd). Food Sci. Technol. Res. 9 (4), 332-337.

Hara, Y., Kobayashi, K., Yamamoto, T., Arai, E. and Matsuda, H. (2003c). The effect of electrolyzed water on production of soybean functional low-molecular weight peptide by an Aspergillus oryzae protease. Nippon Shokuhin Kagaku Kogaku Kaishi. (J. Japanese Soc. Food Sci. Technol.) 50, 419-427 (in Japanese with English abstract).

Hayashibara, T., Kadowaki, A. and Yuda, N. (1994). A study of the disinfection/microbiocidal effects of electrolyzed oxidizing water. Japan J. Med. Technol. 43, 555-561.

Helke, D.M, Sommer, E.B. and Wong, A.C.L. (1995). Attachment of Listeria monocytogenes and Salmonella typhimurium to stainless steel and Buna- $\mathrm{N}$ in the presence of milk and individual milk components. J. Food Prot. 56, 479-489.

Hirano, H. and Ueda, O. (1997). Characteristics of electrolyzed neutral water possibility of the practical use for food hygiene. Shokuhin Kogyo, Japan, 40, 25-35 (in Japanese).

Hotta, K. (1995). Antimicrobial mechanism analysis of acidic electrolyzed water. Abstr. 2nd Functional Water Symp., p. 74 (in 
Japanese).

Hotta, K., Kawaguchi, K., Saitoh, F., Saitoh, N., Suzuki, K., Ochi, K. and Nakayama, T. (1994). Antimicrobial activity of electrolyzed $\mathrm{NaCl}$ solution: Effect on the growth of Streptomyces spp. Actonomycetology 8, 51-56.

Hsu, S.Y. (2003). Effects of water flow rate, salt concentration and water temperature on efficiency of an electrolyzed oxidizing water generator. J. Food Eng. 60, 469-473.

Hurst, J.K., Barrette, W.C. Jr., Michel, B.R. and Rosen, H. (1991). Hypochlorous acid and myeleperoxidase-catalyzed oxidation of iron-sulfur clusters in bacterial respiratory dehydrogenase. Eur. J. Biochem. 202, 1275-1282.

Iseki, M., Takaoka, T., Kondo, Y., Ikematsu, M., Rakuma, T. and Takizawa, K. (2002). The sterilization system of water with electrolysis technology. 26th Seminar Soc. Study Water. pp. 510.

Isobe, S. (2002). Existing situations and problems of electrolyzed water application technology in agriculture. Agriculture of this Month. 7, 19-25.

Isobe, S. (2003). New apparatus, good partnerships and fruitful results. Proc. United States-Japan Cooperative Program in Natural Resources (UJNR) Food and Agriculture Panel 32nd Annual Meeting, Tsukuba, Japan, Nov 9-15, pp. 524.

Iwasawa, A. (1993). Antiviral effects of acidic electrolyzed water. Clinical Microbiology 20 (2), 231-236.

Iwasawa, A. and Nakamura, Y. (1999a). Antibacterial activities and safety of acidic electrolyzed water. Bokin Bobai (J. Antibact. Antifung. Agents) 27 (7), 449-462 (in Japanese).

Iwasawa A. and Nakamura, Y. (1999b). The concept and the problems of acidic electrolyzed water in the medical application. Abst. 6th Functional Water Symp., Tokyo, Nov 25-26, p. 76-77 (in Japanese with Abstract in English).

Iwasawa, A., Nakamura, Y. and Mizuno, T. (1993a). Bactericidal activities of aqua oxidation water against clinically isolated strains. Kankyo Kansen. 8, 11 (in Japanese).

Iwasawa, A., Nakamura, Y., Nakamura, K. and Murai, T. (1993b). Bactericidal effect of aqua oxidation water. Clinical Pharmacology Theory 3, 1555 (in Japanese).

Iwasawa, A., Nakamura, Y., Niwa, T. and Nishimoto, Y. (2002). The influence of $\mathrm{pH}$ on bactericidal effects of strong acidic electrolyzed water. Bokin Bobai (J. Antibact. Antifung. Agents). 30 (10), 635-643 (in Japanese).

Izumi, H. (1999). Electrolyzed water as a disinfectant for fresh-cut vegetables. J. Food Sci. 64, 536-539.

Izumi, H. and Ebihara, M. (2001). Microbiology and quality of fresh-cut vegetables treated with electrolyzed water and sodium hypochlorite solution. HortScience $\mathbf{3 6}$ (3), 527.

Izumi, H. and Suzuki, A. (2000). Microbial evaluation of electrolyzed water treated fresh-cut carrots in CM/MA storage. HortScience 35 (3), 405-406.

Japan Soda Industry Association. (1982). Centurial soda industry in Japan. (http: //www.jsia.gr.jp/sub1-2.html) Accessed February 14, 2005 (in Japanese).

Jay, J.M. (1996). "Modern food microbiology". 5th edn., Aspen Pub., Frederick, Md. pp. 48-49.

Kang, S., Park, S. and Moon J. (2002). Bean vegetables and cultivation thereof using highly electrolyzed water. U.S. Patent 6, 416, 809.

Katta, S.R., Rao, D.R., Dunki, R. and Chawan, C.B. (1991). Effect of gamma irradiation of whole chicken carcasses on bacterial loads and fatty acids. J. Food Sci. 56, 371-373.

Kato, R. (1999). Application of electronically prepared chlorine water in food industry. Abst. 6th Functional Water Symp., Tokyo, Nov 25-26, p. 48-49 (in Japanese with Abstract in English).

Kato, A., Hara, Y., Arai, E. and Oinishi, R. (2001). Preparation method for dough flour foods. U.S Patent No. 6,326,048.
Kawasaki, S., Kawasaki, T., Hayashi, Y., Yoshida, K., Isobe, S. and Isshiki, K. (2003). Inactivation of Norwalk-like Viruses (NLV) by electrolyzed acid water. Bokin Bobai (J. Antibact. Antifung. Agents). 31 (10) 529-533 (in Japanese with English Abstract, Tables \& Figures).

Kikuchi, K. (2000). Cathodic reaction of water electrolysis. Abst. 7 th Annual Meeting Functional Water Symp., pp. 16-17 (in Japanese).

Kim, C., Hung, Y-C. and Brackett, R.E. (2000a). Efficacy of electrolyzed oxidizing (EO) and chemically modified water on different types of foodborne pathogens. Intl. J. Food Microbiol. 61, 199-207.

Kim, C., Hung, Y. and Brackett, R.E. (2000b). Roles of oxidationreduction potential in electrolyzed oxidizing and chemically modified water for the inactivation of food-related pathogens. J. Food Prot. 63, 19-24.

Kim, C., Hung, Y-C., Brackett, R.E. and Frank, J.F. (2001). Inactivation of Listeria monocytogenes biofilms by electrolyzed oxidizing water. J. Food Process. Preserv. 25, 91-100.

Kobayashi, K., Tosa, N., Hara, Y. and Horie, S. (1996). An examination of cooked rice with electrolyzed water. Nippon Shokuhin Kagaku Kogaku Kaishi. (J. Japanese Soc. Food Sci. Technol.) 43, 930-938 (in Japanese).

Kobayashi, K. and Hara, Y. (2004). Effects of electrolyzed water on the color tone of sekihan. Nippon Shokuhin Kagaku Kogaku Kaishi. (J. Japanese Soc. Food Sci. Technol.) 51, 358-366. (in Japanese with English Abstract).

Kohno, M. (1996a). ESR detection of active oxygen. Abstracts 3rd Functional Water Symp., Japan, p. 52 (in Japanese).

Kohno, M. (1996b). Free radical approach to acidic electrolyzed water. Abst. 3rd Functional Water Symp., p. 12 (in Japanese).

Koseki, S. and Itoh, K. (2000a). Effect of acidic electrolyzed water on the microbial counts in shredded vegetables. Nippon Shokuhin Kagaku Kogaku Kaishi. (J. Japanese Soc. Food Sci. Technol.) 47, 722-726 (in Japanese).

Koseki, S. and Itoh, K. (2000b). Effect of acidic electrolyzed water on the microbial counts in shredded vegetables (Part II)Pretreatment effect of alkaline electrolyzed water. Nippon Shokuhin Kagaku Kogaku Kaishi. (J. Japanese Soc. Food Sci. Technol.) 47 (12), 907-913 (in Japanese).

Koseki, S. and Itoh, K. (2000c). Effect of acidic electrolyzed water on the microbial counts in shredded vegetables (Part III)Effect of combined physical supplementary means on the washing and disinfection. Nippon Shokuhin Kagaku Kogaku Kaishi. (J. Japanese Soc. Food Sci. Technol.) 47 (12), 914-918 (in Japanese).

Koseki, S. and Itoh, K. (2000d). Fundamental properties of electrolyzed water. Nippon Shokuhin Kagaku Kokago Kaishi (J. Japanese Soc. Food Sci. Technol.) 47, 390-393 (in Japanese).

Koseki, S. and Itoh, K. (2000e). The effect of available chlorine concentration on the disinfecting potential of acidic electrolyzed water for shredded vegetables. Nippon Shokuhin Kagaku Kogaku Kaishi. (J. Japanese Soc. Food Sci. Technol.) 47 (12), 888-898 (in Japanese).

Koseki, S. and Itoh, K. (2001a). Prediction of microbial growth in fresh-cut vegetables treated with acidic electrolyzed water during storage under various temperature conditions. J. Food Prot. 64, 1935-1942.

Koseki, S. and Itoh, K. (2001b). The effect of acidic electrolyzed water on the quality of cut vegetables. Nippon Shokuhin Kagaku Kogaku Kaishi. (J. Japanese Soc. Food Sci. Technol.) 48 (5), 365-369 (in Japanese with English Abstract).

Koseki, S. and Itoh, K. (2002). Effect of nitrogen gas packaging on the quality and microbial growth of fresh-cut vegetables under low temperature. J. Food Prot. 65 (2), 326-332.

Koseki, S., Yoshida, K., Isobe, S. and Itoh K. (2001). Decontamination of lettuce using acidic electrolyzed water. J. Food Prot. 64 
(5), 652-658.

Koseki, S., Fujiwara, K. and Itoh K. (2002). Decontamination effect of frozen acidic electrolyzed water on lettuce. J. Food Prot. 65, 411-414.

Koseki, S., Yoshida, K., Kamitani, Y. and Itoh, K. (2003). Influence of inoculation method, spot inoculation site, and inoculation size on the efficacy of acidic electrolyzed water against pathogens on lettuce. J. Plant Prot. 66, 2010-2016.

Koseki, S., Yoshida, K., Kamitani, Y., Isobe, S., and Itoh, K. (2004a). Effect of mild heat pre-treatment with alkaline electrolyzed water on the efficacy of acidic electrolyzed water against Escherichia coli O157: H7 and Salmonella on lettuce. Food Microbiol. 21, 559-566.

Koseki, S., Yoshida, K., Isobe, S. and Itoh, K. (2004b). Efficacy of acidic electrolyzed water for microbial decontamination of cucumbers and strawberries. J. Food Prot. 67, 1247-1251.

Kouno, H. (1996). Kyoudenkaisui nouhou (Agricultural Methods Using Strong Electrolyzed Water), Noubunkyou, Tokyo. p. 148. (in Japanese).

Kumon, K. (1997). What is functional water? (Guest Editorial). Artificial Organs 21, 2-4.

Kumon, K. (1999). An efficient use of electrolyzed strong acid aqueous solution in surgical intensive care unit. 6th Functional Water Symp., Tokyo, Nov 25-26, p. 36, (in Japanese with Abstract in English).

LaMondia, J.A. and Douglas, S.M. (1997). Sensitivity of Botrytis cinerea from Connecticut greenhouses to benzimidazole and dicarboximide fungicides. Plant Dis. 81, 729-732.

Lazarovits, G., Abbasi, P.A. and Earl, R. (2003). Use of acidic electrolyzed water for reducing populations by Xanthomonas campestris pv. Vesicatoria on tomato seed and foliage. Canadian J. Plant Pathol. 25, 429.

Lee, S-H. and Frank, J.F. (1991). Inactivation of surface-adherant Listeria monosytogenes by hypochlorite and heat. J. Food Prot. $\mathbf{5 4}, 4-6$.

Len, S-V., Hung, Y-C., Ericksen, M.C. and Kim, C. (2000). Ultraviolet spectrophotometric characterization and bactericidal properties of electrolyzed oxidizing water as influenced by amperage and pH. J. Food Prot. 63, 1534-1537.

Len, S-V., Hung, Y-C., Chung, D., Anderson, J.L., Ericksen, M.C. and Morita, K. (2002). Effects of storage conditions and $\mathrm{pH}$ on chlorine loss in electrolyzed oxidizing (EO) water. J Agric. and Food Chem. 50, 209-212.

Lillard, H.S. and Thomson, J.E. (1983). Efficacy of hydrogen peroxide as a bactericide in poultry chiller water. J. Food Sci. 48, 125126.

Matsuo, M. (1995a). Denkibunkaisui no nougyou eno riyou [1] (Use of electrolyzed water in agriculture [1]) Nougou oyobi Engei. 70, 375-378 (in Japanese).

Matsuo, M. (1995b). Denkibunkaisui no nougyou eno riyou [2] (Use of electrolyzed water in agriculture [2]). Nougou oyobi Engei. 70, 497-502 (in Japanese).

Matsuo, M. and Takahashi. M. (1997a). Kyoudenkaishisui no nougyou nadoni okeru sakkin.bojyo gijutsu [1] (Disinfection and disease control techniques by strong electrolyzed water in agriculture [1]). Nougou oyobi Engei. 72, 693-698 (in Japanese).

Matsuo, M. and Takahashi, M. (1997b). Kyoudenkaishisui no nougyou nadoni okeru sakkin.bojyo gijutsu [2] (Disinfection and disease control techniques by strong electrolyzed water in agriculture [2]). Nougou oyobi Engei. 72, 805-808 (in Japanese).

Matsuo, M. (2000) The basics and application technology of electrolyzed water. Gihodo Shuppan Co. Ltd. pp. 25-46, 289-292 (in Japanese).

Matsuoka, T., Tosa, Y., Miyauchi, K., Fujii, N. and Nakaya, T. (1994). A study on use of electrolyzed water in agriculturephysical characteristics of electrolyzed water and its effect on sanitation and disease control. Abstracts 53rd meeting Agric.
Eng. Soc. pp. $105-106$.

McPherson, L.L. (1993). Understanding ORP's role in the disinfection process. Water Engineering \& Management, November, 29-31.

Moriyama, Y., Kimura, T., Kuroishi, E. and Tabata, K. (2002). Bactericidal activity of electrolyzed water from daily life. Bolkin Bobai (J. Antibact. Antifung. Agents) 30, 65-71 (in Japanese).

Nakagawa, S., Goto, T., Nara, M., Ozawa, Y., Hotta, K. and Arata, Y. (1998). Spectroscopic characterization and the $\mathrm{pH}$ dependence of bactericidal activity of aqueous chlorine solution. Anal. Sci. 14, 691-698.

Nishimoto, Y., Morishita, Y. and Kaizuka, M. (1996). Evaluation of acidic electrolyzed water generally called "Functional water". Bunseki Kagaku (Analytical Chemistry), 45 (7), 701-706 (in Japanese).

Onishi, R., Hara, Y. and Arai, E. (1999). Effect of weak electrolyzed water on the properties of bread. Food Sci. Technol. Res. 5, 388392.

Onishi, R., Hara, Y. and Arai, E. (2000). Improvement of eating quality and preservability of cooked rice obtained from aged rice grains by weak electrolyzed cathode water. Nippon Shokuhin Kagaku Kogaku Kaishi (J. Japanese Soc. Food Sci. Technol.) 48, 112-119 (in Japanese with English Abstract).

Oomori, T., Oka, T., Inuta, T. and Arata, Y. (2000a). The efficiency of disinfection of acidic electrolyzed water in the presence of organic materials. Anal. Sci. 16, 365-369.

Oomori, T., Oka, T., Inuta, T., Ishigouoka, H. and Arata, Y. (2000b). Effects of electrolyzed water on rice grains infected with Burkholderia glumae. Bokin Bobai (J. Antimicrob. Antifung. Agents) 28, 485-491 (in Japanese).

Park, C-M., Hung, Y-C., Doyle, M.P., Ezeike, G.O.I. and Kim, C. (2001). Pathogen reduction and quality of lettuce treated with electrolyzed oxidizing and acidified chlorinated water. J Food Sci. 66 (9), 1368-1372.

Park, C-M., Hung, Y-C. and Brackett, R.E. (2002a). Antimicrobial effect of electrolyzed water for inactivating Campylobacter jejuni during poultry washing. Intl. J. Food Microbiol. 72, 77-83.

Park, C-M., Hung, Y-C. and Kim, C. (2002b). Effectiveness of electrolyzed water as a sanitizer for treating different surfaces. $J$. Food Prot. 65, 1276-1280.

Robbs, P.G., Bartz, J.A., Brecht, J.K. and Sargent, S.A. (1995). Oxidation-reduction potential of chlorine solutions and their toxicity to Erwinia carotovora subsp. Carotovora and Geotrichum candidum. Plant Dis. 79, 158-162.

Schubert, U., Wisanowsky, L. and Kull, U. (1995). Determination of phytotoxicity of several volatile organic compounds by investigating the germination patterns of tobacco pollen. $J$. Plant Physiol. 145, 541-518.

Schoerner, A. and Yamaki, Y.T. (1997). A trial about mildew control of melons with electrolyzed water. Abst. 4th Functional Water Symp., pp. 29-30 (in Japanese).

Schoerner, A. and Yamaki, Y.T. (1999a). Control of powdery mildew of cucumber with electrolyzed water. Japanese Soc. Farm Work Res. 34, 177-183 (in Japanese).

Schoerner, A. and Yamaki, Y.T. (1999b). Possibility of controlling powdery mildew on peach with acid electrolyzed water. Abst. of the IOBC/ISHS Symposium, Belgium.

Selkon, J.B., Babb, J.R. and Morris, R. (1999). Evaluation of the antimicrobial activity of a new super-oxidized water, Sterilox ${ }^{\circledR}$, for the disinfection of endoscopes. J. Hospital Infection 41, 5970 .

Shetty, N., Srinivasan, S., Holton, J. and Ridgway, G.L. (1999). Evaluation of microbicidal activity of a new disinfectant:

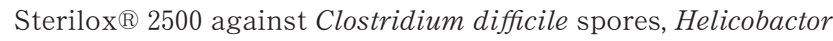
pylori, vancomycin-resistant Enterococcus species, Candida albicans and several Mycobacterium species. J. Hospital Infec- 
tion 41, 101-105.

Shiba, A. and Shiba, K. (1995). "Strong Ionized Water Handbook". Dept of Dentistry, Showa Univ. and Dept. of Dentistry, Tokyo Medical and Dental Univ. Igoku Joho Co. Ltd. Publisher (in Japanese).

Shimada, K., Igarashi, T. and Ebihara, N. (1997) Changes in the properties of soft and hard oxidized waters under different storage conditions and when in contact with saliva. J. Japanese Soc. Periodontol., 39, 104-112.

Shimada, K., Ito, K. and Murai, S. (2000). A comparison of the bactericidal effect and cytotoxic activity of three types of oxidizing water, prepared by electrolysis, as chemical dental plaque control agents. Intl. J. Antimicrob. Agents, 15, 49-53.

Shimizu, Y. (1994). Virucidal/bactericidal effects of electrolyzed oxidizing water in relation to prevention of nosocomial (hospital) infection. Dental J. 40 (1), 145-152 (in Japanese).

Shirahata S. (2001). Reduced water for prevention of diseases. Animal Cell Technology: Basics \& Applied Aspects. 12, 25-31.

Sumida, O. (1998). Redox water and usage of oxidized water using redox water maker. Fresh Food System 26, 21-28 (in Japanese).

Suzuki, T. (1996) Disinfection of microbes and their toxins by electrolyzed water. BioIndustry. 13 (8), 15-27.

Suzuki, T. (1999). Electrolyzed chlor-aqueous solution for food sanitation management: An overview. Abstracts $6^{\text {th }}$ Functional Water Symp., Tokyo, Nov 25-26, pp. 46-47 (in Japanese with Abstract in English).

Suzuki, T. and Watanabe, M. (2000). "Mechanism of killing microorganisms". In: Semjo Sakkin. Nogaku to Gijutsu. Science Forum, Tokyo, pp. 74-86 (in Japanese).

Suzuki, T., Itakura, J., Watanabe, M., Ohta, M., Sato, Y. and Yamaya, Y. (2002a). Inactivation of staphylococcal enterotoxinA with an electrolyzed anodic solution. J. Agric. Food Chem. 50 (1), 230-234.

Suzuki, T., Noro, T., Kawamura, Y., Fukunaga, K., Watanabe, M., Ohta, M., Sugiue, H., Sato, Y., Kohno, M. and Hotta, K. (2002b). Decontamination of aflatoxin-forming fungus and elimination of aflatoxin mutagenicity with electrolyzed $\mathrm{NaCl}$ anode solution. J. Agric. Food Chem. 50, 633-641.

Takagi, H., Arakawa, Y., Hashimoto, K., Dogasaki, T. and Maruyama, T. (1997). Bactericidal effects of electrolyzed water treatment of foods. Abst. 18th Meeting Japan Food Microbiology Soc. p. 71 (in Japanese).

Tamaki, M., Kondo, S. and Sakai, Y. (2001). A study on the control of rice disease by electrolyzed water. Environment Control in Biology 39 (2), 85-101.

Tanaka, H., Hirakata, Y., Kaku, M., Yoshida, R., Takemura, H., Mizukane, R., Ishida, K., Tomono, K., Koga, H., Kohno, S. and Kamihira, S. (1996). Antimicrobial activity of superoxide water. J. Hospital Infection 34, 43-49.

Tosa, N. and Yamasaki, Y. (2000). Effect of organic substances on the residual chlorine contained in the strong acidic electrolzyed water. J. Japanese Soc. Food Sci. Technol. 47, 287-295.

Tuncan, E.U. (1993). Effect of cold temperature on germicidal efficacy of quaternary ammounium compound, iodofor and chlorine on Listeria. J. Food Prot. 56, 1029-1033.

Ueno, R., Kashiwagi, M., Tachibana, S., Aoki, T. and Nada, K. (1999). Applications of several electrolyzed waters for agricultural and fishery fields. Abst. 6th Functional Water Symp., Tokyo, Nov 25-26, pp. 52-53 (in Japanese with Abstract in English).

Vareltzis, K., Soultos, N., Koidos, P., Ambrosiadis, J. and Genigeorgis, C. (1997). Antimicrobial effects of sodium tripolyphosphate against attached to the surface of chicken carcasses. Lebensm.-Wiss. Technol. 30, 665-669.
Venkitanarayanan, K.S., Ezeike, O.I., Hung, Y. and Doyle, M.P. (1999a). Efficacy of electrolyzed oxidizing water for inactivating Escherichia coli O157: H7, Salmonella Enteritidis, and Listeria monocytogenes. Appl. Environ. Microbiol. 65, 4276-4279.

Venkitanarayanan, K.S., Ezeike, O.I., Hung, Y. and Doyle, M.P. (1999b). Inactivation of Escherichia coli O157: H7 and Listeria monocytogenes on plastic kitchen cutting boards by electrolyzed oxidizing water. J. Food Prot. 62, 857-860.

Vivien, M.A., Janet, E.L., Burton, C.H., Whyte, R.T. and Mead, G.C. (2000). Hygiene aspects of modern poultry chilling. Intl. J. Food Microbiol. 58, 39-48.

Wang, H., Feng, H. and Luo, Y. (2004). Microbial reduction and storage quality of fresh-cut cilantro washed with acidic electrolyzed water and aqueous ozone. Food Res. Intl. 37, 848-856.

White, G.C. (1999). Chemistry of Chlorination. In "Handbook of Chlorination and Alternative Disinfectants". $4^{\text {th }}$ edn. John Wiley \& Sons: New York, Chapter 4, pp. 212-287.

Xiong, H., Li, Y., Slavik, M.F. and Walker, J.T. (1998). Spraying chicken skin with selected chemicals to reduce attached Salmonella typimurium. J. Food Prot. 61, 272-275.

Yamaki, Y.T. (1998). Disease control with functional water. Workshop: Sustainable development in horticulture in Asia and Oceania. Nov. 10, 1998. The Univ. Tokyo, Japan. pp. 10-15.

Yamaki, Y.T. and Schoerner, A. (1995). A field trial for estimating the possibility of controlling powdery mildew of cucumber by function water. Abst. 2nd Functional Water Symp. pp. 36-37 (in Japanese with English Abstract).

Yamaki, Y.T. and Schoerner, A. (1996). Possibility of controlling postharvest decay of mandarins by electrolyzed water. Abst. 3 rd Functional Water Symp., p. 32-33 (in Japanese with English Abstract).

Yamaki, Y.T. and Schoerner, A. (1997). A trial of controlling diseases of peaches by electrolyzed water. Abst. 4th Functional Water Symp., pp. 27-28 (in Japanese with English Abstract).

Yamanaka, S. (1995). Hygiene control technology utilizing electrolyzed oxidizing water. Food Processing Technol. 15 (2), 7-16.

Yamanaka, S., Yamashita, K. and Matsuzawa, K. (1995). Food preservation technology with electrolyzed water. Nara prefecture industrial experiment station technical report, pp. 29-31.

Yang, H., Swem, B.L., Li, Y. (2003). The effect of pH on inactivation of pathogenic bacteria on fresh-cut lettuce by dipping treatment with electrolyzed water. J. Food Prot. 68, 1013-1017.

Yoshida, K. (2003). A fundamental and applied researchers on the control of microorganisms using electrolyzed water. Unpublished PhD dissertation. Graduate School of Fisheries Sciences, Hokkaidi Univ., Japan, p. 137.

Yoshida, K., Lim, K-I, Chung, H-C., Uemera, K., Isobe, S. and Suzuki, T. (2001). Sterilization effect and influence on food surface by acidic electrolyzed water. Nippon Shokuhin Kagaku Kaishi (J. Japanese Soc. Food Sci. Techol.), 48 (11), 827-834 (in Japanese).

Yoshida, Y., Min, J-S., Park, J-B., Isobe, S. and Suzuki, T. (2003). Disinfecting rice seeds using acidic electrolyzed water. J. Soc. Agric. Structures Japan 33 (4), 31-37. (in Japanese with English Abstract).

Yourman, L.G. and Jeffers, S.N. (1999). Resistance to benzimidazole and dicarboximide fungicides in greenhouse isolates of Botrytis cinerea. Plant Dis. 83, 569-575.

Zhao, P., Zhao, T., Doyle, M.P., Rubino, J.R. and Meng, J. (1998). Development of a model for evaluation of microbial crosscontamination in the kitchen. J. Food Prot. 61, 960-963.

Zhao, T., Doyle, M.P., Zhao, P., Blake, P. and Wu, F-M. (2001). Chlorine inactivation of Escherichia coli O157: H7 in water. J. Food Prot. 64, 1607-1609. 